\title{
La revolución negra en Saint Domingue y sus efectos en la guerra racial de las Antillas y Tierra Firme, $1789-1797^{*}$
}

\author{
Carlos Alberto Murgueitio Manrique*
}

\section{Resumen}

Este artículo explica el impacto de la revolución francesa en la colonia de Saint Domingue desde 1789 hasta 1797. Incluye los debates celebrados en la Asamblea Nacional en torno a la incorporación de los mulatos al status de ciudadanos de la república con los mismos derechos que los blancos, el inicio de la guerra civil en la porción francesa de la isla entre los diferentes partidos y su degradación hasta generarse el levantamiento de los esclavos y la guerra internacional contra la Gran Bretaña y España.

En esa misma línea argumentativa el autor señala los dispositivos y estrategias empleados por las autoridades españolas, peninsulares y coloniales, para contener los efectos amenazantes de la guerra racial, provocada por un eventual levantamiento negro en las Antillas mayores y Tierra Firme, lugares que como Saint Domingue, estaban dedicados a la economía de plantaciones y mantenían una preponderancia numérica de esclavos de origen africano frente a la población criolla.

\section{Palabras claves}

Revolución negra, Saint Domingue, Política, Siglo XVIII

\section{Abstract}

This article explains the impact of the French revolution in the colony of Saint Domingue from 1789 until 1797. Includes the debates that took place in the National Assembly related to the expansion of citizenship to the mixture breeds who received the same rights as the whites, the beginning of the civil war in the French portion of the island between the different parties and its degradation until the uprising of the slaves and the international warfare against Great Britain and Spain.

In the same argumentative line the author points out the dispositives and strategies employed by the Spanish authorities, peninsular and colonial, to contain the threading effects of racial war, provoked by an eventual black revolt in the big Antilles and Mainland, places like Saint Domingue, that were dedicated to a plantation economy, maintaining a numeric preponderance of African origin slaves in front of the white population.

\footnotetext{
* Artículo tipo 2: de reflexión, según clasificación de Colciencias.

** Politólogo - Universidad de los Andes, Bogotá, Máster en Historia Contemporánea de América, Universidad Central de Venezuela, Caracas. Profesor Asistente, Dpto. de Historia, Universidad del Valle, Cali.
} 


\section{Key words}

Black Revolution,Saint Domingue, Policy, century XVIII.

El innegable éxito que habían tenido las plantaciones azucareras y cafeteras de las Antillas se evidenciaba más que en ningún otro lugar en Saint Domingue, su enorme población esclava que rondaba según la menor de las estimaciones en el medio millón, compartía el espacio con tan solo 30,000 blancos y un número equivalente de libertos, en su mayoría mulatos. La trata sin descanso de esclavos africanos había permitido el florecimiento económico de las plantaciones francesas, que para finales del siglo XVIII representaban el más pujante emporio comercial del Caribe. Saint Domingue no solo producía azúcar para el mercado francés, había comenzado a desarrollar plantaciones de cacao, añil y más recientemente café en las zonas montañosas del este del país, todas habidas de mano de obra esclava impulsaban la demanda sin límites de brazos esclavos sin alertarse del peligro que conllevaría la demografía racial en el futuro cercano.

Saint Domingue era considerada la más rica posesión europea del mundo y superaba en población esclava a sus rivales de los dominios insulares británicos, holandeses y españoles, con proporciones menores. El panorama demográfico se difundía por las demás Antillas francesas, Martinica y Guadalupe, las cuales según el historiador francés Jaques Solé, eran habitadas por 11,000 y 14,000 blancos respectivamente, una población esclava de alrededor de 90,000 cada una, y una población mulata de pocos miles. Las demás Antillas y los territorios fértiles del litoral continental del Caribe aptos para las plantaciones pero en control de España y la Gran Bretaña comenzaban a mostrar los mismos signos demográficos debido al mismo fenómeno de la trata negrera, Jamaica, Barbados, Cuba y la capitanía general de Venezuela presentaban poblaciones negras y pardas numerosas en comparación de la población de origen europeo a finales del siglo XVIII. El historiador cubano José Luciano Franco estima que en esa época las posesiones españolas del Caribe registraban entre un $10 \%$ y un $30 \%$ de población esclava de procedencia africana.

El estudio de la revolución francesa y sus efectos directos en las Antillas, especialmente en la isla de Saint Domingue, es indispensable si pretendemos comprender el inicio de la gran insurrección pre independentista que se presentó en las colonias americanas insulares y continentales a finales del siglo XVIII. Los levantamientos negros y pardos, de esclavos y libertos se sucedieron por la geografía del Gran Caribe, desde las costas de Venezuela a las de Luisiana, desde la isla de Jamaica hasta la de Trinidad, las economías de plantaciones se sentían amenazadas. La característica esencial de estos conflictos era la guerra de castas, nutrida de enorme crueldad manifestada no solo en la estela de muerte arrojada por los partidos raciales, pero también por la destrucción de la capacidad productiva de la isla, la pérdida de sus enormes capitales invertidos y malogrados así como por la huida de la población blanca del territorio, la cual no volvería jamás a ocupar sus propiedades. A la situación interna se sumaban los continuos embargos comerciales y la cuarentena internacional impuesta a la revolución 
negra de parte de los grandes imperios de la época, los cuales buscaban impedir la supervivencia de la revolución al mismo tiempo que su expansión por los demás colonias de plantaciones.

La revolución francesa y su calendario iniciado en julio de 1789 sorprendió al mundo, especialmente a los franceses que habitaban las colonias insulares, al encaminarse los acontecimientos metropolitanos de manera paulatina hacia una radicalización, que traería consigo una transformación definitiva de la situación crucial que vivía el sistema de las plantaciones en las Antillas francesas del Caribe, con la proclamación de la libertad de los esclavos y el reconocimiento de sus derechos de igualdad ante las leyes de la república en febrero de 1794. De esta manera la revolución negra de la isla de Santo Domingo se convertiría en un modelo a imitar por los esclavos en diversos puntos de la geografía americana, precisamente en aquellos lugares en los que existían plantaciones similares, con poblaciones numéricas superiores de esclavos frente a la presencia poblacional de origen europeo.

La Venezuela del siglo XVIII también era un territorio explotado por haciendas de plantaciones cuya producción era realizada por esclavos negros y se concentraba en los valles de la costa y en los llanos del sur. La producción se fundamentaba en la ganadería para la producción de cueros, la agricultura de subsistencia y la de exportación, en la que se incluían artículos como el cacao, el tabaco y el algodón, habiendo sido introducida la producción de caña de azúcar en los valles de Aragua. La población de la capitanía se estimaba a finales del siglo XVIII en 898,043 habitantes, de los cuales la mitad vivían en Caracas. Según las cifras manejadas por Federico Brito Figueroa, la población se dividía en diferentes estratos,

los 172,727 blancos formaban el $20.3 \%$, de los que solo $12,000,1.3 \%$ eran peninsulares. La mayor parte de la población estaba constituida por negros y pardos, que juntos formaban el $61.3 \%$ del total, 407,000 pardos o el $45 \%$, 33,362 o el 4\% de negros libres, 87,000 esclavos negros, 9.7\%, y 24,000 cimarrones, que llegaban a sumar en $2.6 \%$ del total poblacional (Brito Figueroa, 1993, p, 123).

La libertad de los esclavos amenazaba la economía de las plantaciones, principal interés de los criollos y europeos en los territorios caribeños, incluidas dentro de las redes del comercio atlántico y fuente de magníficas fortunas a ambos lados del océano. Resulta sencillo de imaginar que las transformaciones políticas generadas en Francia y sus posesiones americanas por la revolución se convirtieron en fuente de problemas para los otros sistemas coloniales y sus territorios ultramarinos que compartían no solo el vecindario en el Caribe sino además el mismo problema demográfico, una creciente población esclava de origen africano y una pequeña minoría de blancos que controlaban la tierra y el comercio.

La reacción de las autoridades españolas ante la avanzada de la revolución en las zonas de frontera, tanto en Europa como en América se evidenció a partir de la 
creación de instituciones para dirimir problemas del comercio entre criollos y peninsulares como los Consulados, en los dispositivos de seguridad en las fronteras, en los mecanismos de contención, propagandística, de espionaje y militar, dirigidos a las poblaciones americanas para hacerle frente a la preocupación manifiesta de las autoridades metropolitanas y coloniales por una posible expansión de la fiebre revolucionaria en las colonias y a través de alianzas con otras potencias comerciales, como la Gran Bretaña en lucha contra la Francia revolucionaria.

En este pequeño artículo me propongo exponer las disposiciones implementadas por las autoridades españolas del Caribe para controlar la difusión de las ideas revolucionarias, (denominadas como francesas), tanto en el Santo Domingo español, como en Cuba y Venezuela ante las amenazas de un levantamiento negro o pardo de similares características al de Saint Domingue, así como la conexión existente entre las revueltas de negros de Saint Domingue y la de los negros y pardos en las costas de Coro en Venezuela. Para este segundo propósito fue necesario investigar la forma como se filtró la información proveniente de Francia y sus territorios antillanos en medio de una serie persecución a la literatura francesa y a las noticias provenientes de sus territorios, encomendada a la inquisición. Encontrando que pese a los esfuerzos de los españoles de aislar a la colonia francesa e impedir la difusión de sus consignas distribuidas a través de propaganda impresa, la difusión oral y escrita, los sucesos ocurridos en Saint Domingue no pudieron ser contenidos por las autoridades coloniales. Tal y como el historiador venezolano Carlos Edsel comenta en su trabajo, "que grupos de libertos y esclavos seguían los pasos de la revuelta de Saint Domingue a través de las palabras de aquellos que viajaban por el Caribe insular y tenían contactos con los jacobinos negros", (Edsel, 1995, p, 164).

La gesta libertaria de Saint Domingue representó el inicio de la primera gran ola anticolonial de la historia contemporánea y se convirtió en el símbolo de la lucha contra la esclavitud de los negros y de las gentes de color, llevando por primera en vez en la historia la igualdad legal de las razas al hemisferio occidental. Sin embargo, su influencia despertó gran temor en las poblaciones blancas del Gran Caribe, cuestión que determinó el apego de estas a las instituciones imperiales, garantes del orden en el sistema colonial y única fuerza capaz de definir la perdurabilidad de la esclavitud ante un eventual levantamiento negro. El mismo Alexander Von Humbolt hace referencia a este hecho, "la aristocracia venezolana es contraria a la independencia, no ven en las revoluciones sino la pérdida de sus esclavos. Prefieren una dominación extranjera a la autoridad ejercida por americanos de casta inferior" (Von Humbolt, 1965, p, 166).

Jaques Solé comenta que desde la década de 1770 se dieron formación verdaderas bandas de cimarrones que se ocultaban en las montañas de Saint Domingue y amenazaban con incursionar en las plantaciones, cuestión que llevó a los franceses a firmar con sus homólogos españoles de la parte oriental de la isla en 1785, "tratados con las bandas cimarronas otorgándoles la categoría de hombres libres de color", (Solé, 2006, p. 87). Brito Figueroa comenta que en 
Venezuela las rebeliones de esclavos se dieron desde el siglo XVI, pero que desde 1732 se presentaron levantamientos de cimarrones que formaron verdaderos ejércitos guerrilleros que amenazaban a las plantaciones y a las ciudades del litoral, los cuales llegaron incluso a derrotar en el campo de batalla a los soldados imperiales. El camino había sido descubierto por los negros, la manera para lograr el propósito abolicionista era a través de las armas y estas se empuñarían en un primer momento contra los blancos europeos y criollos por igual.

En las décadas previas al estallido revolucionario de 1789 , ya se habían presentado incidentes de relativa trascendencia, tanto en Saint Domingue como en Venezuela, en el primero, con la fuga de los esclavos comandados por Makandal, "que amenazaba con sus planes de envenenamiento masivo a la colonia contaminando los ríos desde sus nacimientos en las zonas montañosas del oriente", (Franco, 1980, p. 22), y en la segunda en la Sierra de Coro, con la aparición de Cocofío, "un misterioso y carismático negro que ejercía en oficio de curandero y brujo, que rodeado de un halo mágico religioso recorría los campos y haciendas pregonando la libertad de los esclavos", (Edsel, 1996, p. 158). La planeación de los levantamientos en la clandestinidad de las reuniones en los campos cercanos a la ciudad de Cap Français y de Coro, el liderazgo de personalidades letradas y respetadas por sus comunidades, sus objetivos encaminados a la emancipación de la esclavitud, la forma de lucha guerrillera y los métodos empleados contra la aristocracia criolla francesa e hispana, a través de saqueos, quemas de las plantaciones y de las haciendas y ejecuciones a los blancos acompañadas de la huída de estos hacia otras regiones del Caribe, son características semejantes en ambos procesos, aunque haya que diferenciarlos en los grados de efectividad y duración.

Los acontecimientos que tuvieron lugar en Saint Domingue desde el inicio de la revolución en la metrópoli francesa han sido motivo de estudio por diferentes académicos, americanos y europeos, a lo largo de los doscientos años siguientes, sin embargo en la mayor parte de las veces el análisis del proceso revolucionario que vivió Saint Domingue ha seguido siendo interpretado como un simulacro que repite la secuencia de los acontecimientos que estaban sucediendo en la metrópoli, sin llegar a explicar una relación directa entre ese proceso revolucionario de vocación antiesclavista de Saint Domingue con sus semejantes, menos exitosos pero igual de desconcertantes para el orden colonial en el continente americano durante los mismos años.

La primera parte de este pequeño trabajo analiza las condiciones en que se encontraba Saint Domingue en el momento del estallido de la revolución en Francia y la forma como las transformaciones ocurridas en la metrópoli condicionaron el inicio de los conflictos raciales en la colonia hasta producirse el levantamiento negro, la intervención internacional, la proclamación de la república y la emancipación de los esclavos. En la segunda parte se enfatiza en la puesta en marcha de dispositivos y estrategias implementadas por las autoridades españolas, ibéricas y americanas para frenar la expansión de las ideas liberales y 
revolucionarias desde Saint Domingue. Haciendo énfasis en el caso particular de la revuelta negra y parda de Coro, se explica la forma como la ideología republicana y libertaria llega a las costas de Tierra Firme superando los obstáculos impuestos por la corona. La tercera parte corresponde al inicio de las primeras conspiraciones republicanas en España y Venezuela en donde se evidencia por vez primera la presencia de intelectuales peninsulares y criollos que abrazaron las ideas consagradas en la declaración de los Derechos del Hombre y del Ciudadano así como las garantías y derechos consagrados en la Constitución francesa de 1791.

El abordaje al problema presenta una clara sincronía temporal, ya que la revolución francesa iniciada en 1789, la posterior guerra de la Convención, de 1793 a 1795, entre Francia y España, la paz de Basilea y el acercamiento del gobierno de Godoy en España a la Francia del Directorio, definen la temporalidad de análisis en América, pues los efectos de esos cambios en las relaciones diplomáticas traen como es natural en la era colonial, consecuencias en los territorios coloniales y en el abordaje de las problemáticas sociales vigentes, tales como el republicanismo o el abolicionismo y la permanencia de la monarquía o la reconfiguración de la institución esclavista. Las similitudes y diferencias en el tratamiento que los distintos gobiernos le dan a estas problemáticas definen las relaciones internacionales del momento.

\section{La abolición de la esclavitud en Saint Domingue, una fórmula republicana para pacificar la guerra racial en el Caribe $(1789-1795)$}

A lo largo del siglo XVIII, las plantaciones francesas de Saint Domingue habían logrado la producción total de azúcar de todos los territorios caribeños de Gran Bretaña juntos. La exportación de este producto al nuevo mercado de los Estados Unidos de América potenció aún más el negocio, pero para cubrir la demanda creciente los colonos franceses tuvieron que importar, según las cifras manejadas por Leslie Bethell, alrededor de 30,000 esclavos africanos anuales en los años que precedieron a la revolución francesa. La trata de esclavos que durante siglos había sido manejada por las compañías comerciales del reino como la Compañía de Guinea, había sido reemplazada por los comerciantes particulares franceses radicados en L'Harve, Burdeos y Nantes, los cuales utilizaron sus capitales para financiar buena parte del crecimiento económico que vivía la más preciada de las posesiones francesas.

Las población mulata en Saint Domingue, que para las fechas del periodo revolucionario sumaba 28,000 personas aproximadamente, amparadas en el Code Noir de Luís XIV, "que en 1685 había sido decretado con el fin de otorgarle a las esclavas negras que contrajeran matrimonio con franceses y a su prole la libertad", (Guerra Vilaboy, 2007, p. 13), empezaban a acumular propiedades respaldadas en los derechos consagrados. Con el paso de un siglo habían logrado apoderarse de $1 / 4$ de la tierra fértil apta para los cultivos de exportación. La población blanca de la colonia desconfiaba de los mulatos, pues estos habían ganado estatus dentro de la sociedad por su participación como soldados del 
ejército del rey en la guerra de independencia de las colonias británicas de Norteamérica en las décadas anteriores, encontrando así un espacio propicio para la ascensión social que les había sido negada en las etapas anteriores.

Las largas estancias de estudio de los mulatos más afortunados en las ciudades francesas, les había permitido además un acercamiento a los círculos intelectuales de la metrópoli, lo que llevó a la formación de fraternidades de apoyo a la causa del reconocimiento de sus derechos políticos plenos, tales como la Societé des Amis de Noirs de París, que en medio de los sucesos propios del ambiente revolucionario, logró presionar a los Estados Generales y a que la Asamblea Constituyente francesa para que concediera, aunque de manera ambigua el voto a los mulatos propietarios de Saint Domingue el 8 de marzo de 1790, "este hecho desencadenó la furia de los colonos blancos que se levantaron contra la nueva administración de París y sus aliados mulatos" (James, 2006, p. 82).

En la Asamblea francesa, la alianza de los plantadores y los diputados de los grandes puertos atlánticos había logrado frenar en una primera instancia el debate en torno a los derechos que reclamaban los mulatos y libertos. El denominado club Massiac financiaba panfletos y artículos de prensa que buscaban atemorizar al público francés ante un eventual levantamiento de esclavos orquestado por los amigos de los negros. Como era natural, los colonos temían que las nuevas ideas se expandieran y contaminaran las islas del Caribe, lugar en donde estos debates se seguían y podrían llegar a tener verdaderas repercusiones, los colonos insistían en "que el estatuto peculiar de jerarquías raciales de las colonias estaba ligado con el sistema de la esclavitud, y que al reconocer derechos de igualdad política a los mulatos se atentaba con el poder de los blancos y con los intereses franceses de ultramar", (Solé, 2006, p. 95).

El otorgamiento de los derechos políticos por la Asamblea a los mulatos propietarios, llevó a que estos sectores poderosos sentaran las bases de una autonomía absoluta de las autoridades coloniales con la fundación de la Asamblea de colonos en la ciudad de Saint Marc ${ }^{1}$, ubicada en la costa central de la isla. Los mulatos que hasta ese momento tan solo reclamaban los derechos de igualdad para su pequeña comunidad numérica ante la Asamblea francesa, organizaron inicialmente su poder en el valle del río Cahos, rodeado por las montañas del mismo nombre, en la ciudad de Mirebalais cerca a la frontera española. La división de los blancos frente a los mulatos dirigidos por Vincent Ogé y Jean B. Chavannes terminó desencadenando una guerra civil. Los mulatos tomaron las armas tratando de forzar al gobernador conde de Peynier a cumplir los decretos revolucionarios, pero fueron derrotados en la primera instancia ${ }^{2}$.

\footnotetext{
1 La Asamblea colonial de Saint Marc, órgano que representaba las aspiraciones autonomistas y posteriormente independentistas de los grandes blancos y sus aliados, parte de los pequeños blancos, los realistas franceses y posteriormente los ingleses, dividía el territorio colonial en tres entidades, heredando la división administrativa definida por la metrópoli asignando una representación de 80 representantes del norte, 64 del oeste y 58 del sur.

${ }^{2}$ Algunos de los mulatos lograron huir al Santo Domingo español pero fueron capturados y entregados por las autoridades francesas y ajusticiados el 25 de febrero de 1791. El historiador cubano José Luciano Franco
} 
Tras los enfrentamientos, los colonos blancos de Saint Marc firmaron con los libertos el pacto de Croix des Bouquets, el 11 de septiembre de 1791, en el que se estipulaba la igualdad de derechos entre los blancos, los mulatos y libertos. Los mulatos y sus aliados blancos ${ }^{3}$ organizaron su poder en el sur y el oeste en torno a la ciudad de Port au Prince. Este pacto fue producto de la necesidad de los blancos de negociar con los mulatos ante el inicio de la guerra de los negros en el norte de la colonia, pero tan solo duraría un par de meses, pues el 21 de noviembre los disturbios generados en Port au Prince terminaron provocando una matanza general de mulatos dirigida por el maltés Pralotto y la desaparición de 4/5 partes de la ciudad, ocasionada por los incendios registrados. El caos político y la guerra se tomaron de nuevo el sur del país, mientras en el norte, los blancos estaban siendo sorprendidos ante el avance de las hordas negras levantadas por el llamado de la guerra racial que convocaba el exterminio de los blancos y de sus plantaciones buscando con la destrucción de la economía la inviabilidad del régimen colonial.

Las autoridades francesas tenían una larga experiencia en la guerra contra las guerrillas cimarronas, siendo difícil comprender cómo estas no estaban listas para repeler una ofensiva. James y Dubois coinciden en aclarar que el gobernador Blanchelande, enfrentado en un principio a los mulatos se preocupaba mucho más "en los brotes de la chusma blanca de las ciudades, siempre dispuestas al pillaje y al vandalismo", que de una revuelta esclava, al considerar incapaces a los negros de organizar un movimiento a gran escala capaz de amenazar y destruir el poder colonial francés. El efecto de la sorpresa fue un acierto sin parangón, la desaparición del poder blanco en la zona más rica de la colonia tendría efectos devastadores para la economía y restringiría las posibilidades de un triunfo militar en el futuro.

El inicio de esta guerra es atribuido por el historiador cubano José Luciano Franco a la "agitación creada alrededor de los esclavos de la colonia ante la guerra emprendida por los mulatos, a los espectáculos a los que asistían y a los

\footnotetext{
comenta que la represión impuesta por las autoridades de Saint Domingue no tuvo los efectos esperados, pues los libertos se reunieron nuevamente el 7 de agosto de ese año en la iglesia de Saint Louis de Mirebalais para concertar una acción política, resolviéndose de nuevo por las armas. La comandancia de este nuevo esfuerzo militar de los libertos recayó en los hombros de los veteranos de la guerra de independencia de los Estados Unidos de América, hombres como Bauvais, André Rigaud y Henri Chistophe. "Sus escasas fuerzas estuvieron integradas por 300 negros cimarrones, endurecidos en la lucha de guerrilleros montañeses, que prestaron una cooperación decisiva en el combate de Pernier, donde fueron derrotadas las tropas blancas de Port au Prince", Ver: Franco, José Luciano. (1989). Ensayos sobre el Caribe. La Habana: Editorial de Ciencias Sociales. p, 20.

${ }^{3}$ Los pequeños blancos, grupo compuesto por funcionarios, pequeños comerciantes, intelectuales, artesanos y plantadores, que se mostraron inicialmente favorables al gobierno que representaba a la Asamblea Constituyente francesa y el curso democrático de la revolución, cambiaron de partido ante el reconocimiento de los derechos de la gente de color, cuestión que evidencia que sus aspiraciones "se limitaban a repartirse las propiedades de la gente de color, preservar la esclavitud, la discriminación racial y a compartir el poder con los grandes blancos", Ver: Césaire, Aimé. (1967). Toussaint Louverture. La revolución francesa y el problema colonial. La Habana: Instituto del Libro. P. 95.
} 
discursos que escuchaban de sus amos". Sin embargo, su interpretación de los acontecimientos estaba condicionada en buena parte por la ignorancia y la superstición $^{4}$, y en otra por la confusión, producto de la manipulación de la información difundida al público por las autoridades. La experiencia les había demostrado a los guerrilleros cimarrones de Saint Domingue, que llevaban más de un siglo sumando enfrentamientos con las autoridades francesas en las montañas, que las tentativas aisladas estaban condenadas al fracaso, y por eso habían venido preparando un levantamiento de masas invocando la fuerza conspiradora y aglutinadora del vodú.

Laurent Dubois sostiene que la mayor parte de los esclavos de la isla eran nacidos en África y que estos ni siquiera sabían hablar francés, pero que desde su experiencia en las guerras de ese continente se nutrieron para llevar a cabo una guerra prolongada en el tiempo, con la implementación de técnicas de combate irregular e implacable en cuanto a los métodos utilizados contra el enemigo,

Conciben en que la guerra reside la formación de pequeños grupos autónomos que multiplican ataques y retiradas para desorientar al enemigo. Combaten en forma dispersa y emprenden la ofensiva cuando están seguros de ganar. Observando cuidadosamente al enemigo, alternan la prudencia y la audacia. Se protegen con obstáculos naturales y las técnicas de emboscada tienen siempre resultados certeros (Dubois, 2004, p. 102).

Todos los autores coinciden en nombrar a Boukman como al gestor principal del levantamiento, ya que este enorme negro originario de Jamaica oficiaba como papaloi o alto sacerdote del culto del vodú y ejercía una gran influencia dentro de los esclavos de las plantaciones cercanas a Cap Français. El levantamiento fue un movimiento de masas metódicamente preparado y orquestado, el plan había sido fraguado a escala gigantesca e implicaba exterminar a los blancos y apoderarse de la colonia. Carentes de armas, los esclavos de las plantaciones estaban a la espera de la señal que determinaría el inicio de la operación. Armados de flechas envenenadas, según comenta Dubois, tratarían de obstaculizar el avance francés.

En la noche del 14 de agosto de 1791, recordada por haberse presentado una tormenta tropical, acompañada de relámpagos ráfagas de viento y densos chaparrones, se efectuó la reunión de Bois Caïman, cerca de Morne Rouge, presidida por Boukman, quien dio sus últimas instrucciones en medio de los conjuros del vodú, decidiéndose que los esclavos de los barrios rurales de Cap Français iniciarían la movilización incendiando las plantaciones de sus amos durante la noche del domingo 21 de agosto y serían seguidos en toda la región del

\footnotetext{
${ }^{4}$ En un principio podría haber sido contagiada la asimilación de los hechos entre los esclavos, como un atentado de los revolucionarios contra la el "buen" rey Luís XVI, partiendo de imágenes que rayaban en la fantasía, llegando incluso a difundirse entre estos, la idea de que el monarca había sido apresado por las autoridades republicanas por haber otorgado la libertad a los esclavos. Este hecho es importante para comprender el porqué parte de los líderes de la revuelta negra entraron en cooperación con las autoridades españolas, las cuales armaban a los guerrilleros y compraban su alianza con promesas falsas y mentiras. Ver: James, C.L.R. (2001). Los jacobinos negros. México: Fondo de Cultura Económica. P. 56.
} 
norte. La sublevación estalló a los ocho días acordados, en las palabras de Franco,

las masas de siervos respondieron a los roncos sones del tambor que retumbó de hacienda en hacienda en toda la región norteña. Armados de machetes, hachas cuchillos, al grito de libertad y venganza, se lanzaron con irresistible furia sobre los blancos. Arrasaron, quemaron y mataron implacablemente a cuantos propietarios hallaron en su camino (Franco, 1980, p. 23).

James relata la manera como las partidas de esclavos asesinaron a los amos de la plantación de Gallifet y quemaron las instalaciones hasta los cimientos, "las medidas de seguridad que había tomado Blanchelande preservaron a Le Cap, pero la preparación había sido meticulosa y exhaustiva, y al cabo de pocos días la mitad de la llanura del norte era un despojo llameante", (James, p. 93). Luego el mismo autor explica el grado de devastación en que quedó la región, "durante casi tres semanas los habitantes de Le Cap apenas pudieron distinguir el día de la noche, mientras una lluvia de caña quemada, impulsada por el viento como copos de nieve se abatía sobre la ciudad y las embarcaciones, presagiando la destrucción completa de la población y el puerto", (James, p. 93).

Esta sublevación trastornó en pocas semanas la economía de una de las regiones más ricas del mundo. Dubois sostiene que

en los ocho primeros días se habían destruido más de doscientas plantaciones y hacia finales de septiembre, las que estaban situadas en un perímetro de 80 kilómetros alrededor de Cap Français habían dejado de existir. En las montañas vecinas se habían devastado más de mil plantaciones de café, y se habían instalado en ellas los grupos rebeldes que sumaban varias decenas de miles de hombres. Mientras sus víctimas explicaban los hechos por un deseo puro y simple de saqueo y matanza, sin observar que al destruir las bases del sistema que los sometía ala esclavitud y al matar a sus dirigentes, buscaban la libertad (Dubois, p. 109).

Muchos jóvenes mulatos se apresuraron a unirse a los negros en el norte, en pocas semanas las fuerzas negras y mulatas rebeldes llegaron a sumar 100,000 hombres.

La guerra racial había iniciado, los blancos la habían emprendido contra los mulatos y ahora las enormes hordas de esclavos negros amenazaban no solo a los blancos y sus propiedades ${ }^{5}$, pero la misma existencia de la colonia y de la

\footnotetext{
${ }^{5}$ Césaire concibe tres especies de guerras en Saint Domingue, las guerra de los negros contra los blancos, la guerra de los mulatos contra los blancos y la guerra de los blancos entre sí, mostrando el grado de ruptura existente entre los sectores blancos, grandes y pequeños, monárquicos y republicanos. Mientras las insurrecciones negra y mulata se daban la mano, los blancos se enfrentaban en los partidos y radicalizaban sus posturas, los unos estrechando una alianza con la Gran Bretaña, los otros formando con los mulatos del sur un bloque de apoyo a la república francesa en proceso de formación. Ver: Césaire, Aimé. (1967). Toussaint Louverture. La revolución francesa y el problema colonial. La Habana: Instituto del Libro. P. 24.
} 
soberanía francesa en el Caribe. En noviembre de 1791 llegaron a Cap Français los comisarios del gobierno constitucional enviados a pacificar la colonia, el grupo estaba conformado por Roume, Mirbeck y Saint Léger, quienes entraron en contacto con Jean François y Biassou, al mando de 40,000 hombres habían asumido el mando de la insurrección negra tras la muerte de Boukman, durante el combate de Fond Bleu unas semanas antes. Dos negros libres, Raynal y Duplessis fueron enviados a St. Marc con el fin de notificarles a los blancos de las disposiciones conciliatorias de la metrópoli con los líderes de la revuelta, pero estos rechazaron tajantemente cualquier forma de negociación con comisionados que carecían de legitimidad política ante sus ojos.

Las hostilidades se reanudaron y el 15 de enero de 1792, las partidas guerrilleras lideradas por Jean François tomaron la población fronteriza de Ounaminthe, en el noreste, mientras Biassou fracasó en su ofensiva sobre Cap Français realizada los días 22 y 23 de enero, días después de la ejecución del monarca francés y a su reina en una plaza pública de París. Aprovechando la situación, Brissot logró hacer progresar la causa de la gente libre de color en la Asamblea, la cual proclamó finalmente el 4 de abril de ese año, la igualdad política de los mulatos y los negros libertos en las colonias intentando restablecer el orden en Saint Domingue. La nueva situación llevó a que los mulatos movilizaran a grupos de negros en el centro y sur de la isla, ofreciéndoles la libertad ${ }^{6}$, mientras los blancos los imitaban transformando a parte de sus esclavos en soldados libres.

La guerra continuó y se prolongó indefinidamente, tanto por causas de origen metropolitano como por las propias contradicciones internas dentro del territorio antillano, llenando a la colonia de horrores, en donde los bandos enfrentados rivalizaban con sus actos de crueldad y destrucción. El general francés Pamphile de Lacroix, quien combatió a los revolucionarios escribió en sus Memorias,

La guerra no fue más que un exterminio en la cual los partidos se superaron en furor, los negros sorprendidos ocultándose eran inexorablemente degollados. Cuando los blancos marchaban a los combates, destruían en la ceguera de su venganza, todo lo que era negro, a veces el esclavo fiel que se presentaba confiado, perecía bajo los golpes del amo irritado. Esas crueldades reclutaban a la rebelión (Lacroix, 1820, p. 146).

Al año de iniciarse la rebelión, grupos armados tanto mulatos como negros dominaban buena parte de la isla y sus jefes exigían de común acuerdo el final de la esclavitud. Los blancos habían perdido poder en la isla e influencia en la

\footnotetext{
${ }^{6}$ Rigaud, jefe de los mulatos, tomó la ciudad de Port au Prince con ayuda del ejército conformado por esclavos a los cuales les ofreció la libertad a cambio de mantener el orden en las plantaciones. Pese a las advertencias, muchos de los esclavos que habían participado en la campaña abandonaron los campos y establecieron núcleos de resistencia en las montañas que iniciaron ataques contra las plantaciones meridionales. En el norte, los jefes de la rebelión negra trataban de negociar con la asamblea colonial y los comisarios de Paris el compromiso de deponer las armas a cambio de la abolición de la esclavitud y de una amnistía general. De esta manera, los esclavos volverían entonces a las plantaciones solo como trabajadores asalariados. Ver: James, C.L.R. (2001). Los jacobinos negros. México: Fondo de Cultura Económica. P. 167.
} 
metrópoli, muchos habían huido y los que quedaban, lo único que podían esperar era que los ingleses intervinieran para amparar sus vidas y propiedades, sometiendo de nuevo a los esclavos a cambio de beneficios comerciales. En medio de este panorama llegaron a la ciudad de Cap Français emisarios franceses de la recién inaugurada república el 17 de septiembre de 1792, acompañados de abundantes efectivos militares bien armados que sumaban una fuerza total de 6,000 hombres, tenían como objetivo la pacificación de la colonia y el aplastamiento de las insurrecciones blanca y negra, así como desalojar a las potencias extranjeras que se habían aprovechado de la situación.

Los comisarios civiles Sonthonax, Polverel y Ailhaud, acompañados por los comandantes militares D'Eparbes, (que reemplazaría como gobernador a Blanchelande), D'Henisdal, Montesquieu, La Salle, asignados al norte, sur y oeste respectivamente, ejercerían el gobierno de la colonia. Los nuevos comisarios estaban resueltos a introducir los cambios necesarios para restablecer el orden y mejorar la suerte de los esclavos y dictaron las órdenes oportunas para llevar a efecto sus propósitos. Sonthonax gobernaba el norte, donde los blancos se resignaban a regañadientes al triunfo de la revolución y los mulatos se aferraban a los puestos de poder. Acorralados por las operaciones de los británicos en el oeste y de los españoles en el este, con sus respectivos aliados de los partidos enfrentados, los representantes republicanos tan solo contaban con los mulatos y algunos blancos que se les habían sumado.

El 13 de abril de 1793, las fuerzas republicanas lograron tomar control de Port au Prince, pero en el mes de junio Cap Français cayó en poder del general Galbaud tras una incursión naval exitosa del ejército expedicionario que logró expulsar a los comisarios y sus fuerzas. Galbaud sustituyó momentáneamente a D'Esparbes como gobernador general, los blancos acogieron su gobierno al declararse este representante de los propietarios de esclavos. Al ponerse del lado de los subversivos dueños de esclavos y contando con el apoyo de más de 3,000 hombres bien armados, se definió un enfrentamiento contra los comisarios civiles de la república y el reducto de los efectivos militares liderados por Sonthonax, entablándose un furioso combate durante los días 21 y 22 de junio.

En vista de que no podría ser posible una victoria frente a las fuerzas ocupantes por no poder recibir refuerzos de la asediada república, Sonthonax, que para ese momento representaba al mando supremo de la representación republicana tomó una resolución memorable, convocó a los esclavos negros de los alrededores de la ciudad a combatir a los blancos insurgentes a cambio de perdón y libertad. Su invitación hizo que 20,000 negros se abalanzasen sobre Galbaud y sus blancos, según palabras de James, "Los marineros de Galbaud, ebrios de vino y de victoria, empezaban a entregarse al pillaje apenas cesados los combates cuando los negros emprendieron el descenso desde las colinas de la ciudad", (James, p. 128). La participación de las hordas negras permitió la victoria del gobierno republicano en esa importante región de la isla. 
La contrarrevolución huyó hacia el puerto abandonándolo todo en su retirada. Galbaud tuvo que arrojarse al mar para huir en un bote que lo llevaría al exilio, mientras la ciudad del Cap era víctima de un incendio que devoró dos terceras partes de sus edificaciones. La decisión de abolir la esclavitud había sido el último recurso para preservar la soberanía francesa de Saint Domingue, "El 29 de agosto de 1793, en una solemne ceremonia celebrada en Cap Français, Sonthonax proclamó la libertad absoluta de los esclavos y sus plenos derechos como ciudadanos de Francia", (Guerra, 2000, p. 17). Los franceses solo quedaban con el recurso de ganar la simpatía de los negros del norte si querían defender las fronteras de su colonia y esto solo fue posible con el pliego de las concesiones ofrecidas ${ }^{7}$.

Para la república francesa era de primera importancia impedir la conquista de toda la colonia por las tropas invasoras hispano británicas. De darse la ocupación total el imperio colonial de la Francia revolucionaria desaparecería, sus vastos recursos pasarían a los bolsillos de sus principales enemigos y la Gran Bretaña ${ }^{8}$ podría volver a Europa y lanzar su ejército y su marina contra la revolución. El derrocamiento de los monarcas franceses y el posterior regicidio habían radicalizado a los blancos, pero las disposiciones de los nuevos comisarios acerca de la prohibición de la trata negrera y la plena igualdad civil de los blancos, mulatos y negros habían rebozado los límites de la imaginación ${ }^{9}$.

El acceso de los antiguos esclavos a la ciudadanía suprimió toda barrera racial, lo que constituyó un desafío sociopolítico de un alcance inusitado para la época, marcando la historia de América. La abolición decretada por la Convención, había

\footnotetext{
${ }^{7}$ Buena parte de los negros que participaron en la toma del Cap Français no siguieron al lado de los comisarios republicanos, pues como se ha comentado anteriormente, los españoles habían cautivado a los esclavos negros con falsas promesas de tierras y con el uso de una iconografía monárquica, más comprensible para las masas que la propaganda republicana. Del lado español continuaron los líderes del cimarronato negro Jean François y Biassau con sus 10,000 negros, los dos habían sido nombrados lugartenientes generales de los ejércitos del rey de España. Toussaint Louverture, hasta diciembre de 1793 había sumado importantes victorias para los españoles contra los franceses. Estos triunfos militares le otorgaron a España el dominio sobre un cordón occidental en el territorio francés desde la frontera hasta el mar, aislando por un tiempo las provincias del norte con el occidente y el sur. Ver: Césaire, Aimé. (1967). Toussaint Louverture. La revolución francesa y el problema colonial. La Habana: Instituto del Libro. P. 256.

${ }^{8}$ A la intervención española desde Santo Domingo había que sumarle la incursión de la Royal Navy, la cual había desembarcado en Jeremie, región noroccidental de la isla, 900 hombres provenientes de Jamaica el día 19 de septiembre de 1793. Los británicos, defensores de la esclavitud habían recibido el apoyo de los blancos propietarios y de cierto número de mulatos reaccionarios en la provincia occidental y a comienzos de 1794 estaba ya en sus manos toda la fachada marítima del golfo de Port au Prince, exceptuando la capital, la totalidad de la provincia occidental, gran parte del sur, salvo la parte controlada por Rigaud y la fortaleza de Mole Saint Nicolas. Los británicos proyectaban sus ambiciones sobre todo el Caribe, el 3 de febrero de ese mismo año enviaron un destacamento desde Barbados con 7000 hombres y 19 navíos, que en dos meses capturó las Antillas francesas menores, Martinica, Guadalupe y Santa Lucía cayeron una tras otra.

9 La disposición relacionada con la abolición definitiva de la esclavitud en las colonias fue finalmente consagrada por la Convención francesa el 4 de febrero de 1794. La confirmación de la noticia por los líderes de las fuerzas guerrilleras negras determinó el apoyo de los ejércitos negros y las masas esclavas, mientras "los esclavistas reaccionaron ante estos hechos históricos, incrementando en todo el Caribe la propaganda injuriosa contra la Revolución Francesa y el acta de libertad de los esclavos. Unidos a los funcionarios y oficiales realistas se incorporaron a los invasores ingleses y españoles", Ver: Franco, J. L. (1989). Ensayos sobre el Caribe. La Habana: Editorial de Ciencias Sociales. P. 28.
} 
provocado que la jefatura negra aliada a los españoles cambiara de bando, el primero en hacerlo fue Toussaint Louverture en mayo de 1794, siendo nombrado de manera instantánea Comandante General de la línea francesa del oeste. Por un año combatió las partidas de otros líderes negros que permanecían fieles a España y a los ingleses en diversos puestos de la costa, que tras ser tomados por sus hombres, izaban el pabellón tricolor y proclamaban la libertad general de los esclavos. Era innegable que la participación masiva de los esclavos negros y de los libertos y mulatos había sido la pieza clave para que Francia volviera a tomar el control de su colonia más preciada y que lograra deshacerse con el tiempo de las fuerzas invasoras ${ }^{10}$.

Al finalizar la guerra, Saint Domingue estaba en ruinas por los estragos causados por la guerra civil y la abolición de la esclavitud, que había significado el colapso de la burguesía comercial e industrial francesa que no volvería a ver florecer el esplendor de antaño. Además, la nueva jefatura militar de la isla caía en las manos de un mando unido de generales mulatos y negros entre los que se destacaban Alexandre Petion, André Rigaud y Louis Jaques Bauvais por los primeros y Toussaint Louverture ${ }^{11}$, Jean Jaques Dessalines, Henri Chistophe, por los segundos.

Louverture se había consagrado a la tarea de expulsar a los ingleses y a los españoles del territorio francés. El Tratado de Basilea de 1795, firmado entre la Francia republicana y la España borbónica, gobernada por Manuel de Godoy, no solo garantizaba la permanencia de la soberanía francesa en Saint Domingue, sino que ampliaba su territorio con la inclusión de la parte española en una sola entidad política controlada por la Francia republicana. La guerra se libraría desde entonces tan solo contra los ingleses, que aun dominaban las costas de la isla amparados en su formidable flota naval, Jeremie, Port au Prince, Saint Marc y Mole Saint Nicolas seguían ocupadas por los ingleses al mando del general Thomas Maitland.

\section{Los ecos de la guerra racial en las Antillas y Tierra Firme, un ejemplo a evitar en el imperio español (1791 - 1795)}

\footnotetext{
${ }^{10}$ Al tiempo que cambiaba la correlación de fuerzas en Saint Domingue favoreciendo a los republicanos franceses y a sus aliados negros y mulatos, siete barcos franceses comandados por Víctor Hugues, desembarcaron un ejército de 1,500 hombres en Guadalupe, logrando ganar de nuevo para Francia esa preciada posesión que había sido invadida por los ingleses desde el mes de abril de ese mismo año de 1794. Los ingleses habían abolido todas las mejoras que los negros habían obtenido con la revolución, volviendo a restablecer con todo su vigor el régimen anterior a 1789. Hugues aprovechó la situación garantizándoles la libertad a los esclavos y pronto logró formar un ejército negro infundiéndoles el mensaje revolucionario y los vistiéndoles con los colores de la república, logrando derrotar a los ingleses en 1795.

${ }^{11}$ Louverture era el más respetado por parte de los comisarios civiles de la república, entre los que se destacaba Sonthonax y el nuevo gobernador republicano Laveaux. La estrecha amistad que este par de personajes habían depositado en Louverture en medio de la guerra y el éxito rotundo de su campaña contra los ingleses, representada en la victoria de los negros en la población de Mirebalais en el valle del río Artibonite del centro del país, indujo a que Sonthonax lo designara Comandante en Jefe del Ejército francés en Saint Domingue.
} 
Durante la guerra de la Convención, 1793 - 1795, España luchó tanto en Europa como en América contra las ideas del liberalismo radical que se había apoderado de Francia. La naturaleza del enemigo implicó generar una campaña ideológica que lograse la conquista de la opinión, buscando desacreditar al republicanismo y a la democracia, concebidos como parte de la herejía ante la cual había que emprender una cruzada. La contribución a la que asistieron las fuerzas retrógradas de la nación; la aristocracia, el clero, la plebe analfabeta y fácil de manipular, pudieron encabezar el movimiento de resistencia y "volver a conferir legitimidad o vigor a unas instituciones y a unas nociones expuestas a la caducidad, tales como el absolutismo monárquico de origen divino, la cruzada ideológica y religiosa, la inquisición, la intolerancia y el ultramontanismo", (Aymes, p. 364).

Las autoridades españolas debieron construir una reacción frente a los franceses que exaltara los valores patrióticos para darle sentido a la movilización popular e incentivar su contribución a la guerra al mismo tiempo que se apuntaba a reforzar la vieja estructura del antiguo régimen ante la menor amenaza de ruina. Para esto era necesario tomar medidas para la prevención de alborotos con una política represiva de orden público ${ }^{12}$. Los enfrentamientos entre españoles y franceses también ocurrieron con mayor fuerza en los territorios en donde ambas metrópolis compartían posiciones, y ese lugar era precisamente el Caribe, en donde ambas potencias controlaban sus respectivas colonias y donde los efectos producidos por la revolución francesa se sintieron desde un primer momento.

Con el levantamiento de Saint Domingue la revolución dejó de ser un peligro remoto para devenirse en un peligro inminente. La preocupación de las autoridades españolas en 1791 era latente y se demuestra en las instrucciones que el conde de Floridablanca dio a los virreyes y a los gobernadores del Caribe.

\footnotetext{
${ }^{12}$ En la Cédula Real del 31 de mayo de 1789, Carlos IV anunció su Código Negro. Esta jugada política buscaba ganar para la causa realista el favor de los mulatos, zambos y pardos, a los cuales se les permitía gozar de ciertos privilegios tanto económicos como en el servicio militar. En los territorios del Caribe español el Código Negro no se aplicó, las autoridades pensaban que este provocaría la pérdida total del respeto y la obediencia de los esclavos hacia sus amos blancos. En Caracas, pese al ocultamiento del Código, manos anónimas lo pusieron en circulación. Sus imágenes representaban el degollamiento de un hombre blanco por un negro esclavo, razón por la que le es atribuida su publicación a los jacobinos negros. Ver: Edsel, C. (1996). José Leonardo Chirino y la insurrección de la serranía de Coro de 1795, insurrección de libertad o rebelión de independencia. Mérida: Universidad de los Andes. P. 161. La Real Cédula regulaba la educación y las ocupaciones de los esclavos, el trato que debían darles los amos, y se le otorgaba al Procurador Síndico de los ayuntamientos americanos el carácter de protector de los esclavos. Esta medida levantó los ánimos y reclamaciones de los dueños de ingenios y minas así como de los hacendados de distintos lugares de América. El temor a que los esclavos - interpretando mal el contenido - se sublevasen y el consecuente daño que ocasionaría al comercio y en general a los intereses económicos, fueron los principales motivos aducidos por los gobernantes y hacendados de todas las ciudades. Alarmados, el gobernador de La Habana y los vecinos de esta ciudad, en 1789 y 1790, pidieron que la Real Cédula no se publicase y presionaron para que no se cumpliera. Las presiones de los hacendados y los temores a que los acontecimientos de Guárico (Saint Domingue), se extendieran por las posesiones españolas animaron al Consejo de Indias a dictaminar en 1795 que no se pusiera en práctica la Real Cédula de 1789 hasta que no concluyera la guerra y se viera como quedaban los asuntos negros. Ver: González Ripoll, M. D. y otros. (2004). El rumor de Haití en Cuba: temor, raza y rebeldía, 1789 - 1844. Madrid: Consejo Superior de Investigaciones Científicas. pp. 89 - 90.
} 
Floridablanca, Primer Ministro del nuevo gobierno de Carlos IV tomó medidas para evadir el contagio revolucionario en sus dominios americanos. Las autoridades de La Habana, Santo Domingo, San Juan, Caracas, Luisiana, Trinidad y Cartagena, fueron alertadas sobre los efectos de la revolución en Saint Domingue, "El cierre de las fronteras de España vino acompañado de órdenes dirigidas a los virreyes, gobernadores y capitanes generales de las colonias americanas, para mantener constante vigilancia, e impedir la circulación de impresos revolucionarios y de noticias que pudiesen hacer peligrar el dominio español" (Franco, 1965, p. 7).

Por medio de la Real Orden del 24 de septiembre de 1789, Floridablanca había prevenido a los obispos y prelados eclesiásticos, acerca de la introducción de los libros e impresos franceses. Su propósito era preservar a España del contagio revolucionario a toda costa y se apresuró a tomar las medidas necesarias para mantener a los españoles en la ignorancia de los acontecimientos franceses. John Lynch hace alusión al incremento del número de tropas en las fronteras pirenaicas acompañado de la censura y de una vigilancia estricta en los puertos para impedir la entrada de periódicos franceses,

Un edicto de la Inquisición de diciembre de 1789 prohibía la introducción de publicaciones procedentes de Francia relativas a la revolución, sobre la base que estas obras, intentaban establecer un sistema de independencia de toda autoridad legítima y difundir las producciones de una nueva raza de filósofos, hombres de mente corrompida, cuyo objetivo era construir sobre las ruinas de la religión y de la monarquía esa libertad imaginaria que erróneamente suponen que la naturaleza otorga a todos los hombres (Lynch, 1999, p. 340).

Pese al despliegue de medidas, la literatura subversiva encontraba formas para evadir los controles y penetrar los amplios territorios españoles, tanto en Europa como en América. Floridablanca movilizó a la Inquisición a actuar con más energía contra los exponentes de la llustración. Los funcionarios de la Inquisición fueron estacionados en los puestos aduaneros para revisar todo el material procedente de Francia, reforzó el cordón de tropas en las fronteras y en el interior del imperio destinó equipos de espías para descubrir conversaciones subversivas. Floridablanca concebía a los territorios de Cuba, Santo Domingo y Puerto Rico como los principales elementos defensivos del imperio americano, ellos trazaban los lineamientos de la política imperial en el Caribe y el Golfo de México. La guerra contra Francia iniciada en 1793 tanto en Europa como en el teatro americano, (Saint Domingue), implicó que las autoridades del Santo Domingo español y de la vecina Cuba tomaran medidas que variaron desde la promoción de la guerra hasta el bloqueo económico y la cuarentena.

Tras el regicidio del 21 de enero de 1793, las autoridades republicanas de la Francia revolucionaria se preparaban para la guerra con España en los Pirineos y en el Caribe. En carta a los comisarios civiles de la república, fechada el 26 de febrero, el ministro Monge alertaba a los franceses y mulatos a proceder contra los enemigos españoles, así lo resalta el siguiente documento, 
Debe tratar a los españoles como enemigos, debe desplegar todos nuestros medios para tratar de quitarles su porción de la isla, cuya tierra languidece sin cultivo bajo sus brazos holgazanes. Que aquellos que no tienen bienes en Saint Domingue marchen sobre la parte española, encontrarán tierras que podrán hacer fértiles, comprometa a los hombres de color a armarse contra esos nuevos enemigos (Archivo Nacional de La Habana, f. 2).

En marzo de 1793, La Habana y Santiago de Cuba recibieron la Real Orden comunicada en España el 25 de enero de 1793 como respuesta a la ejecución pública de Luís XVI. El documento reza de la siguiente manera, siendo incierto el éxito que tendrán las negociaciones con Francia por más que el rey las desee feliz, me ha mandado S.M. encargar a V.E. que sin pérdida de tiempo expida órdenes convenientes a los Capitanes y Comandantes Generales y demás Gefes militares, a quienes corresponda, y con particular cuidado a los de las Américas, para que procedan con la necesaria precaución, de suerte de que se esté en todas partes con vigilancia y precaución para cualquier caso que puedan ser acometidos (Archivo Nacional de La Habana, f. 4).

La advertencia de las autoridades ibéricas a las caribeñas por el peligro que se registraba en las fronteras se había manifestado inclusive meses antes del regicidio, precisamente a causa de la llegada de los habitantes blancos de Saint Domingue que huían con sus familias y con lo que habían podido rescatar de sus pertenencias al lado oriental de La Española y a la isla de Cuba. Este fragmento nos muestra el cometido,

Pero si de resultas se formaran cuerpos de malhechores, de piratas en esos mares, o de negros contra blancos para destruir a estos, o cometer atrocidades o latrocinios, procuren obrar conforme a las reglas de humanidad, auxiliando a los perseguidos con víveres, armas y municiones según se pudiese y con la demostración de fuerzas marítimas y terrestres que le proporcionasen, poniendo a la vista en que el contagio de la insurrección no se comunique a las partes y posesiones españolas (Archivo Nacional de La Habana, f. 7).

Cada una de las autoridades caribeñas del imperio español tomaron medidas que dependieron de las circunstancias e intereses particulares, Joaquín García, gobernador de Santo Domingo, tras perseguir a los sublevados en la zona de frontera con la vecina colonia les proporcionó recursos para continuar las hostilidades frente a las autoridades francesas y promocionó en el ejército español a los principales jefes negros Biassou, Jean François y Louverture. Esto con el fin de expandir los dominios de España en la isla, aprovechando la coyuntura internacional y dividiendo aun más los partidos y la guerra civil que vivía la colonia de la república francesa. La política del gobernador García generó gran malestar entre las autoridades hispánicas de América, la veían como un peligro para los intereses esclavistas en la región, ya que al promocionar a los negros les otorgaba un status de igualdad, así como la paga de botines y una legitimidad política a su causa, favorable a la emancipación. 
El gobernador de Cuba, Luís de las Casas, percibía la creciente ola revolucionaria en la cercana isla como un grave peligro y adoptó desde el inicio una política combativa contra la liberación de los esclavos que consistía en auxiliar a los colonos franceses que huían de Saint Domingue, frenar las compras de esclavos africanos con el fin de fomentar la colonización blanca, y aislar a la revolución negra de Saint Domingue combatiéndola por todos los medios posibles,

emplearon todos los recursos de que podían disponer para desacreditarla, y llegaron, de acuerdo con los demás esclavistas del Caribe, a trazar planes y ponerlos el práctica para impedir se desarrollo y su progreso, prohibiendo incluso las relaciones comerciales para obligar a los negros de Saint Domingue a someterse de nuevo a la explotación esclavista (Franco, 1965, p. 16).

De las Casas tuvo que enfrentar de cerca las consecuencias de la revolución de Saint Domingue. El Estrecho de los Vientos que divide las dos islas se convirtió con la guerra en un lugar de tránsito para los ejércitos británico y español y para los habitantes, en antaño grandes y pequeños propietarios blancos que huían de la colonia francesa y buscaban asentarse en las ciudades de Santiago de Cuba ${ }^{13} y$ Cienfuegos. De las Casas recibió además a las autoridades del gobierno constitucional depuesto por los jacobinos. El 29 de abril de 1793 arribó a Santiago de Cuba M. Desombrage, quien había sido comandante militar en Jeremie, dispuesto a tratar con el gobernador de Cuba la intervención de este en Saint Domingue, invitación que fue rechazada. El gobernador no comprometió sus recursos pero adoptó una política implacable frente a los republicanos, los cuales al ser arrestados fueron encerrados en las fortalezas del Príncipe, el Morro y la Cabaña ${ }^{14}$.

La negativa de las autoridades cubanas no dejó más alternativa a los colonos y comerciantes blancos de Saint Domingue que convocar el apoyo de los británicos de Jamaica. En septiembre de 1793, se firmó un convenio con los británicos mediante el cual los propietarios franceses entregaban el dominio político de la colonia a los ingleses, con tal de que se aniquilaran las conquistas de la revolución, restableciendo la esclavitud y la trata. El día 20 de septiembre se realizó el desembarco británico en Jeremie, comandado por el general Whitelocke. "Los británicos fueron acogidos por los blancos franceses con gritos de vivan los ingleses y el rey Jorge", (Franco, 1965, p. 40). En esos meses que siguieron

\footnotetext{
${ }^{13}$ La colonia francesa de Santiago de Cuba, la cual comenzó a desarrollarse desde el inicio de la guerra en Saint Domingue, se fue extendiendo con el paso de los años hasta convertirse en el barrio Tívoli de la ciudad actual. Algunos de los franceses que lograron escapar con sus pertenencias y esclavos pudieron establecerse, en la ciudad y compraron tierras en la Sierra Maestra para iniciar la siembra de café en la isla de Cuba.

${ }^{14}$ Mientras los soldados y marinos franceses capturados se enviaban a Filadelfia con el fin de enviarlos en barcos neutrales a Francia, a los negros capturados se les dejaba encerrados en las fortalezas o se les deportaba a otras colonias en las que los negreros los vendían como esclavos. "En el castillo del Morro, (27 de febrero de 1797, permanecían bajo vigilancia del oficial Rafael Pérez, los individuos de color procedentes de Bajayá, que por franceses se hallaban depositados en el castillo", En: Fondo de correspondencia a los capitanes generales. Archivo Nacional de La Habana, Legajo 49, Folio 2.
} 
fueron nombrados los representantes Venault y Charmilly como parte del Consejo de Seguridad y Ejecución del plan de los colonos y comerciantes blancos de Saint Domingue en Jamaica, organismo que era el legítimo gobierno de la isla para los británicos.

La Luisiana también era un centro amenazado por una eventual revuelta negra, la población esclava del territorio sobrepasaba enormemente a la de origen europeo y su carácter continental y selvático había sido un terreno fértil para los levantamientos negros en las décadas precedentes. En julio de 1794 se había concertado una amenaza republicana, pero el barón de Carondelet, gobernador de ese territorio administrado por España, logró someter el brote condenando a la ejecución de 37 personas blancas y negras que había orquestado la liberación de los esclavos. Las autoridades españolas, en guerra contra la Francia republicana, mantuvieron relaciones cordiales con las británicas en el Caribe durante esos años. Obedeciendo a la alianza que habían estrechado las metrópolis, de las Casas suministró a Lord Balcarrés gobernador británico de Jamaica, una jauría de perros adiestrados en la cacería de cimarrones, con tal de dominar a la insurrección negra que estaba ocurriendo en aquella isla vecina a finales de ese año, según relato de Franco.

El 7 de junio de 1793, el Secretario del Real y Supremo Consejo de Indias dirigió una nota al Capitán General de Venezuela, Pedro Carbonell, llamando la atención sobre los designios del gobierno de Francia y de algunos revolucionarios franceses, como de otros promovedores de la subversión en dominios de España en el Nuevo Mundo, los cuales enviaban a las costas de Tierra Firme libros y papeles perjudiciales para la religión, la quietud pública y la subordinación de las colonias. El Supremo Consejo encargó a Carbonell "recogiese los libros y papeles que hubiesen entrado en Venezuela, y se apoderase hasta de la correspondencia privada, si averiguaba que algunos la tuviesen con el reino de Francia ó con extranjeros que atizasen las tendencias revolucionarias, ó con otras personas sospechadas de propagandistas"15. El Capitán General, comprometido en la defensa de las ordenanzas recibió el 23 de septiembre del mismo año otra comunicación, esta vez de Antonio Valdez, miembro del Consejo de Indias en la que se alertaba sobre el llamado de algunos individuos de la Asamblea francesa que se habían propuesto introducir en América un manifiesto sedicioso para suscitar a los habitantes por todos los medios a sacudir el yugo de la dominación española, siguiendo el ejemplo de Francia. Para lo cual habían copiado cientos de ejemplares que enviaron por todas las vías posibles para que llegasen el mayor número posible.

La voz de alerta y reacción oportuna ante las amenazas provenientes de las ideas liberales en el imperio español contenían además de la persecución y represión

\footnotetext{
${ }^{15}$ Casos se vieron en Venezuela en que sin previo aviso se presentó la autoridad en las casas de algunos esposos o padres de familia reclamando las obras de Rousseau o de Voltaire o algunas de las publicaciones relativas a la revolución francesa. Ver: Blanco, J. F. \& Aizpurúa, R. (1989). Documentos para la historia de la vida pública del Libertador. Caracas: Ediciones de la Presidencia de la República. P. 247.
} 
ante cualquier manifestación, la puesta en marcha de dispositivos jurídicos para armonizar las relaciones comerciales con los criollos, las cuales se habían caracterizado en las décadas anteriores por haber sido polémicas. La creación de los consulados de Caracas y de Cartagena era un esfuerzo en ese sentido. La institución se encargaría de la administración de justicia ${ }^{16}$ en los pleitos mercantiles y a la protección del comercio en todos los ramos. La creación de los consulados en 1793, cuando la revolución francesa minaba los tronos de Europa con las máximas de la exagerada democracia, fue una disposición atrevida. Establecía con ella en Venezuela y en la Nueva Granada, asambleas numerosas y electivas, que se renovaban periódicamente y que mantenían amplias facultades para deliberar sobre materias importantes y ejecutar sus acuerdos. De esta forma, otorgándoles derechos de representación a los criollos buscaba ganar sus lealtades, asegurada debido a los miedos generados por los levantamientos de negros y pardos en la sociedad criolla.

Carlos Edsel nos comenta que el decreto de la abolición de la esclavitud en Francia, fechado el 4 de febrero de 1794, fue ampliamente divulgado especialmente en los dominios españoles insulares y de Tierra Firme. Su distribución según el autor, es atribuida no solo a los criollos liberales contagiados por las ideas revolucionarias, sino a los jacobinos negros,

esclavos o mulatos libres dotados de una capacidad innata de liderazgo político, quienes a esfuerzo propio y a escondidas de sus amos blancos habían aprendido a leer y escribir. Circulando entre sus encallecidas manos libros, folletos y documentos con los cuales se publicitaba la revolución francesa. Su inteligencia fuera de lo común, su originalidad y sagacidad para realizar tareas de proselitismo político. Su camuflada y silenciosa labor entre las esclavitudes corianas fueron preparando el clima que se requería para que estallara la insurgencia revolucionaria del zambo Chirino en 1795 (Edsel, 1995, p. 161).

En 1795 se presentó una revuelta de negros y pardos en Tierra Firme, precisamente en la región de Coro, centro de la industria azucarera y la base de la aristocracia blanca. El movimiento estaba dirigido por José Leonardo Chirino ${ }^{17}$ y

\footnotetext{
${ }^{16} \mathrm{La}$ administración de justicia estaba a cargo del tribunal que era compuesto del prior y dos cónsules, que conocían a profundidad todos los pleitos y diferencias que ocurrían entre comerciantes o mercaderes, sus compañeros o factores, sobre sus negociaciones de comercios, compras, ventas, cambios, seguros. Los consulados además debían mandar y supervisar la construcción de caminos para mejorar el comercio al tiempo que fomentar la navegación, la adecuación de puertos y la construcción de muelles. Ver: Blanco, J. F. \& Aizpurúa, R. Ibíd. P. 257.

${ }^{17}$ José Leonardo Chirino era hijo de un esclavo negro de la familia coriana Chirino, sin embargo, nació libre al ser hijo de una mujer india. Sus hijos y mujer eran esclavos de la familia Tellería, mientras él se empleaba como jornalero en la hacienda El Socorro. José Caridad González era un mulato liberto que se había establecido por un tiempo en Curazao, pero mantenía correspondencia con la Real Audiencia de Caracas y con la Corte Española. Se hizo famoso al ganar un litigio por la posesión de las tierras ubicadas entre la ciudad de Coro y las tierras altas de la Serranía, frente a los terratenientes esclavistas Juan Antonio Zárraga y José Zavala. Por iniciativa de las autoridades coloniales se les había concedido las tierras a una comunidad de 200 negros loangos o de Guinea, quienes diligentemente se dedicaron a las labores agrícolas y en poco tiempo lograron una importante producción que en grado considerable abastecía a la ciudad. Según el historiador
} 
José Caridad González, negros libres que habían viajado por el Caribe y que conocían los sucesos de Francia y Saint Domingue. El levantamiento sumó a 300 esclavos que proclamaron el 10 de mayo de $1795^{18}$, la ley de los franceses, la república, la libertad de los esclavos y la supresión de los impuestos de alcabalas. El autor William J. Callahan, argumenta para el caso de la revuelta de la Serranía de Coro, "que la presencia de los negros influidos por las nuevas ideas de igualdad contribuyó a la insurrección de esclavos que ocurrió en las Sierras de Coro durante el año de 1795”, (Callahan, 1967, p. 201). Según su versión, los líderes de la revuelta, el caudillo zambo José Leonardo Chirino, y el negro liberto de origen curazoleño, Josef Caridad González, habían viajado con frecuencia por el Caribe, el primero a Curazao y el segundo tanto a esa isla holandesa como a Saint Domingue y las otras Antillas francesas.

De estos viajes surgiría la interpretación defendida por buena parte de la historiografía venezolana, de que los insurgentes, negros libres, esclavos y un reducido número de indios, proclamaron el establecimiento de la república, la ley de los franceses, la libertad de los esclavos, la destrucción de la nobleza blanca y la abolición de ciertos impuestos como la alcabala. La vinculación a las ideas francesas de esta revuelta ha sido motivo de controversia entre los historiadores venezolanos. El gran historiador falconiano Pedro Manuel Arcaya es partidario de darle trascendencia a la interpretación que apoya un papel destacado a los idearios republicanos, tal y como lo dice en este apartado, "desde los comienzos de la revolución francesa llegaban a Venezuela noticias de esta. A Coro llegarían a través de la Guaira y Curazao. Además, durante el trascurso de la guerra franco española de 1793 - 1795, aparecían con frecuencia los corsarios franceses en las cercanías del puerto de la Vela", (Arcaya, 1979, p. 123).

Al igual que el maestro Arcaya, Federico Brito Figueroa ${ }^{19}$, destaca las relaciones que los líderes de la insurrección anteriormente mencionados mantenían con el exterior a través de los viajes, la correspondencia y por las informaciones recibidas en los puertos por los marineros de las diferentes nacionalidades acerca de los acontecimientos desarrollados en Saint Domingue y las demás Antillas, que conjuraban simultáneamente levantamientos de esclavos contra todos los imperios

coriano Manuel Arcaya, este personaje ilustrado solía viajar con frecuencia a las islas de Curazao, Martinica y Saint Domingue, en donde su personalidad inquieta lo llevó a entrar en contacto con los jacobinos negros. Ver: Arcaya, M. (1979). La insurrección de los negros de la serranía de Coro: 10 de mayo de 1795. Caracas: Academia Nacional de Historia.

${ }^{18}$ El teniente justicia mayor de Coro, Mariano Ramírez, avisó al presidente gobernador y capitán general de Venezuela, que en el día 11 y siguientes de mayo, había ocurrido con motivo de la sublevación de los negros, zambos y mulatos libres y esclavos de la serranía de Coro, confabulados con otros de aquella ciudad. A lo que agrega que dando cuenta de los hechos a la Audiencia, se condenaron 21 reos a la pena de muerte, a 23 loangos, (negros del Congo) y 7 indios a seis y diez años de presidio a ración sin sueldo. El documento está fechado el 28 de junio de 1795. Ver: Blanco, J. F. \& Aizpurúa, R. Ibíd, p. 259.

${ }^{19}$ Brito Figueroa comenta que entre 1760 y 1770 se habían refugiado en el litoral coriano más de 400 cimarrones provenientes de las colonias extranjeras. Según su interpretación, los negros fugados de las Antillas y refugiados en las costas venezolanas constituyeron una importante vía de penetración de la nueva ideología. Ver: Brito Figueroa, F. (1996). El problema de la tierra y los esclavos en la historia de Venezuela. Caracas: Universidad Central de Venezuela. P. 225. 
europeos. Se observa así el desarrollo de una serie ininterrumpida de guerra de guerrillas en la región del Gran Caribe las cuales tienen sus raíces en las insurrecciones que se sucedieron en diferentes momentos a los largo del siglo $\mathrm{XVIII}{ }^{20}$.

Otros autores tales como Ramón Aizpurua definen a la sublevación de negros y pardos de la Serranía de Coro como un movimiento social reivindicativo, siendo más una reacción natural frente a la carga impositiva de las entidades coloniales con los súbditos de colores y no una insurrección que trajera dentro de sus propósitos la emancipación de de los esclavos y la formación de una república a la francesa. Esta interpretación desvirtuaría a la anterior, al darle un matiz menos radical. Aizpurua sostiene que las reivindicaciones eran económicas, destinadas a mejorar el nivel de vida o status social, expresándolas en su lucha a través del odio a los blancos. El rechazo al cobro de la alcabala, considerado por los rebeldes, según Aizpurua como abusivos y desconsiderados sería el detonante de la insurrección, siendo el problema de la esclavitud algo secundario y la influencia de las revoluciones francesa y haitiana algo tangencial.

Esta interpretación negaría el hecho de que las noticias de los acontecimientos en el Caribe fueron conocidas en Tierra Firme y le daría el levantamiento de Coro un significado particular que la incapacitaría dentro de la lógica de la expansión de las ideas revolucionarias. José Gil Fortoul comenta en su obra Historia Constitucional de Venezuela, que en ese territorio del imperio español,

comenzó el movimiento revolucionario por el año de 1795, con la sublevación de negros y pardos de Coro, en la cual se notó la influencia de las revoluciones angloamericana y francesa, influencia que predominaría en las primeras formas constitucionales de la independencia. Aquellos negros y mulatos en secreta connivencia con algunos blancos, proclamaron la ley de los franceses, la república, la libertad de los esclavos y la supresión de algunos impuestos (Fortoul, 1964, p. 156).

Pese a que las diferencias que se tengan otros autores con la interpretación defendida por Aizpurua es fundamental reconocer que las condiciones para que iniciara el levantamiento se dieron tras la llegada a la ciudad de Coro de Juan Manuel Iturbe, tesorero de la Real Hacienda, el cual se empeñó en cobrar puntualmente tributos e impuestos, principalmente las alcabalas que se habían extendido a todas las transacciones. Durante las noches previas al 10 de marzo de 1795 José Leonardo Chirino empezó a tramar su conspiración a través de reuniones realizadas en las haciendas de los alrededores de Coro, como Las

\footnotetext{
${ }^{20}$ En el caso de Venezuela desde se habían presentado durante el siglo XVIII dos grandes levantamientos de esclavos, el primero de ellos es conocido con el nombre de su líder Andresote, el cual había ocurrido en los valles de Yaracuy y Tucacas, y había puesto en aprietos a las expediciones militares enviadas desde Caracas para destruirlos durante los años de 1732 y 1734. La segunda insurrección de esclavos fue liderada por el negro Guillermo entre 1771 y 1774, en la región del sur de Caracas, específicamente en los valles del Tuy y Panaquive, región en la que los insurrectos liberaron esclavos y castigaron las propiedades de los terratenientes. Ver: Arcaya, P. M. (1979). La insurrección de los negros de la serranía de Coro: 10 de mayo de 1795. Caracas: Academia Nacional de Historia.
} 
Macanillas y El Socorro, con los negros Juan Cristobal Acosta y Juan Bernardo Chiquito. Los móviles de la rebelión se planeaban de manera simultánea en el campo y la ciudad, por lo que Chirino se había puesto en contacto con José Caridad González, que había ofrecido su concurso y el de sus partidarios y amigos extranjeros que andaban por el litoral. Según Manuel Arcaya el plan de González consistía en tomar Coro e invadir Puerto Cabello y Maracaibo contando con la ayuda de corsarios franceses.

José Leonardo Chirino liderando un pequeño ejército de 400 hombres descendió de la montaña a media noche del 25 de marzo y tomó por sorpresa la aldea de Caujarao. Al día siguiente el levantamiento se inauguró con el asalto sobre las haciendas El Socorro, Barón, La Magdalena y Sabana Redonda, las cuales fueron saqueadas y quemadas mientras se asesinaba a sus dueños. Los insurrectos robaron los bienes de las haciendas y las casas de los campesinos y arrastraron a muchos esclavos y libertos que se encontraban prófugos por los montes y riscos de la Serranía de Coro. Tras la muerte de algunos hacendados de la región, los guerrilleros acordaron la marcha sobre la ciudad, con el fin de forzar a las autoridades a reconocer la libertad plena de los esclavos y la exención absoluta de los nuevos impuestos, además de cometer una venganza contra los funcionarios de la aduana, incluido el teniente de Justicia Mayor y su familia, además de las ejecuciones de los algunos blancos por suponerlos insensibles frente a los malos tratos que sufrían.

Carlos Edsel relata la forma como los blancos $^{1}$ pudieron salvar sus vidas y propiedades ayudados por las autoridades coloniales,

Los blancos que lograron salvar sus vidas huyeron a esconderse a los montes. Llevaron luego la noticia a la ciudad de Coro. El teniente Justicia Mayor de Coro procedió a formar milicias y a tomar otras medidas, tanto para defender la ciudad de un posible ataque como para proceder a la represión sistemática de la revuelta (Edsel, 1995, p. 126).

El gobernador y capitán general de Venezuela, Pedro Carbonell fue informado de los hechos y se dispuso a informar al Despacho Universal de Guerra en España, tal y como aparece registrado en este documento,

Se le presentaron en número de más de trescientos cincuenta y batiendo la bandera le hicieron embajada en la que pedían libertad para los esclavos y exención de las alcabalas y demás contribuciones para los libres, con el fin de establecer la república, que torpe y delincuentemente envolvían en sus ideas y procuraban con la atrocidad de sus manos manchadas en la sangre de sus amos y otros blancos destrozados ya el furor de su ignominia (A.G.N., f. 3).

\footnotetext{
${ }^{1}$ El exterminio de la nobleza blanca y de sus privilegios sociales y económicos formaba una de los cuatro objetivos que identificaban las consignas junto a la abolición de la esclavitud, la conformación de una república y la eliminación de los tributos y del estanco. Muchos de los blancos acosados con la idea de ver repetida la experiencia de Saint Domingue huyeron a las Antillas holandesas por la Vela de Coro. Ver: Edsel, C. y otros. (1996). José Leonardo Chirino y la insurrección de la serranía de Coro de 1795, insurrección de libertad o rebelión de independencia. Mérida: Universidad de los Andes.
} 
La rápida reacción de las instituciones corianas, tenientes, corregidores, y comandantes militares, que velaban por el orden y la seguridad de los ricos terratenientes, logró someter a la insurrección en tan solo tres días. El teniente Mariano Ramírez Valderraín, con apoyo de los ciudadanos prominentes entre los que se contaba al tesorero de la Real Hacienda, Juan Manuel de Iturbe, y con la ayuda de indios milicianos, organizó la defensa de la ciudad y la persecución inicial de los insurrectos. Caracas reaccionó rápidamente con el envío de armamento y pertrechos requeridos y 50 hombres dirigidos por el comandante e ingeniero militar Francisco Jacot. La mala organización de los sublevados y la pésima calidad de sus armamentos, en los que se contaban tan solo machetes, tuvo que enfrentarse a las milicias de Coro, bien dirigidas y armadas de dos cañones, fusiles, lanzas, sables y arcos con flechas aportados por los indios de la península de Paraguaná.

A la derrota de la guerrilla siguió la persecución para la cual se organizaron dos expediciones destinadas al valle de Carimagua y a las montañas de Macuruca y Gueque, con el fin de capturar a los cabecillas de la rebelión que habían logrado escapar, entre los que se encontraba el propio Chirino. La cacería a Chirino terminó con su captura en el mes de agosto ${ }^{2}$. El desenlace de la insurrección estuvo signado por la represión sistemática de los alzados y la prisión de sus familiares y conocidos, tenidos por sospechosos. Más de 80 de los insurrectos capturados fueron fusilados y degollados, los demás fueron enviados a las fortalezas de Puerto Cabello y La Guaira, mientras a los elementos cercanos a González que conformaron el batallón que llevaba su nombre en la insurrección fueron condenados a la pena en las galeras. Chirino fue interrogado en Caracas durante varios días, Arcaya nos comenta en su trabajo, que Chirino negó cualquier vinculación con los franceses o con González, "exponiendo como motivos del alzamiento los abusos de los propietarios y de las autoridades locales contra los esclavos e indios", (Arcaya, 1979, p. 53).

A finales del verano, en el mes de agosto del mismo año, tanto en el oriente de Cuba como en Curazao ${ }^{3}$, ocurrieron otros levantamientos de las mismas características. En Cuba, el levantamiento era liderado por el mulato Nicolás Morales. La conspiración de Bayamo inició según el historiador cubano José Luís Franco de la siguiente forma,

\footnotetext{
${ }^{2}$ Luego de ser enviado a Coro fue puesto en Caracas en donde fue sentenciado a muerte por la Real Audiencia el 10 de diciembre de 1796. Fue condenado a morir ahorcado y luego de descuartizado su cuerpo fue disperso en diferentes poblaciones de la provincia de Venezuela.

${ }^{3}$ En Curazao la sublevación estuvo marcadamente empapada de consignas libertarias francesas, originadas por una parte del ambiente afrancesado de muchas de las conversaciones y discusiones ocurridas en la isla entre los propietarios y comerciantes blancos a causa de las novedosas circunstancias vividas en Europa, así como de la contestaría influencia de los haitianos entre la propia población esclava y liberta. Ver: Edsel, C. (1996). José Leonardo Chirino y la insurrección de la serranía de Coro de 1795, insurrección de libertad o rebelión de independencia. Mérida: Universidad de los Andes.
} 
Morales, influenciado por la revolución francesa y el cercano ejemplo de la revolución en Saint Domingue, comenzó una activa propaganda entre los bayameses, blancos y de color, para demandar con las armas en las manos de las autoridades coloniales no solo la igualdad racial sino también la extinción de las alcabalas y otros impuestos que pesaban sobre las clases pobres del pueblo, (Franco, 1965, p. 43).

El éxito de esta conspiración fue comprometido por la reacción oportuna del capitán Francisco Sánchez, el cual les comunicó las sospechas a las autoridades de Santiago acerca de la planeada insurrección. El gobernador de las Casas logró castigar con severidad a Morales y sus partidarios.

La guerra entre la república francesa y la España borbónica finalizó el 22 de julio de 1795 mediante la firma del Tratado de Basilea, gestionado por el ministro español, Manuel de Godoy. Las autoridades de Cuba se enteraron de la firma de la paz el 27 de octubre, cuando apareció frente a las costas de Santiago de Cuba una escuadrilla naval francesa con bandera de parlamento, los comandantes de la expedición enviaron una carta acompañada de una proclama del general francés Laveaux de Saint Domingue, en la que oficializaba el anuncio de la paz entre las potencias. El gobernador de Santiago, Juan Nepomuceno de Quintana, facilitó a los barcos de la república girondina algunos víveres y les permitió permanecer el tiempo indispensable para reparar sus averías.

El Santo Domingo español pasaba a administración francesa, siendo el territorio escogido por España para ser cambiado por las provincias vascas y catalanas ocupadas por el ejército de la república en los años de 1794 y 1795. El costo de la guerra en Saint Domingue había trastornado las finanzas de la colonia española y se aproximaba la inminente invasión de las tropas negras victoriosas y legítimamente consagradas a la administración y defensa de la parte francesa de la isla. Santo Domingo fue desocupado, las fuerzas militares y las burocracias locales fueron enviadas a Puerto Rico, Caracas y Cuba. Un éxodo inició en las poblaciones de la isla, "monjas, sacerdotes, familias criollas, la urna con los restos de Cristóbal Colón, oficiales de la Real Hacienda, criados, esclavos, todos emprendieron la huida hacia Santiago y La Habana", (Franco, 1965, p. 43).

El gobernador de las Casas, organizó la recepción de sus compatriotas dominicanos y de los monarquistas franceses que habían dejado su tierra y buscaban emprender camino en Cuba. Prohibió la entrada a la isla a los negros que habían colaborado con España en Saint Domingue contra las fuerzas republicanas de Francia, al tiempo que resaltaba tales las disposiciones para los principales caudillos y sus auxiliares. Uno de los casos más conocidos fue el de el general negro Georges Biassou, el cual pretendía refugiarse en Cuba con su esposa y veintitrés familiares más pero las autoridades de Santiago les negaron la entrada y fueron arrestados y enviados a la desértica Florida. 
La Paz de Basilea ${ }^{4}$ inauguraba una nueva alianza de España con Francia, objetivo que se consolidó con el Tratado de San Ildefonso el 18 de agosto de 1796. Manuel de Godoy, el ministro que había firmado la paz con Francia, sabía que esa paz traería sus consecuencias en sus relaciones con la Gran Bretaña, la cual rechazaría de plano cualquier tipo de acercamiento que revitalizara la alianza tradicional de sus principales competidoras en el sistema colonial. Este tratado significó la participación de España en la guerra contra la Gran Bretaña al lado de la república francesa, guerra que tuvo un carácter marítimo y de enfrentamiento por el comercio y los dominios de América.

Francia dejaba de ser un rival por su peligrosidad social y se convertiría un competidor económico dentro de los mercados peninsulares. Las armadas francesas y españolas actuaban en conjunto, único modo de poder representar una amenaza frente al poderío naval inglés. Hasta 1795 España había salido relativamente indemne de las guerras revolucionarias, pero a raíz de la guerra contra la Gran Bretaña cambió drásticamente esa situación, provocándose una crisis social. Pese al poderío de su flota, no logró impedir el bloqueo de sus puertos, al tiempo que la longitud de sus rutas comerciales marítimas las hacía vulnerables a la piratería. Estos problemas generaron la parálisis del comercio marítimo español y la interrupción del flujo de lingotes procedentes de los territorios imperiales americanos.

\section{Las primeras conspiraciones republicanas en España y Venezuela (1795 - 1797)}

La alianza con la Gran Bretaña le había registrado a España un beneficio en la reducción del contrabando, sin embargo, el mayor porcentaje de los envíos que hacía España al nuevo mundo eran artículos extranjeros, que alcanzaban según las cifras de Bethell, el $62 \%$ de las exportaciones registradas hacia América. Según el mismo autor, Cádiz, que de antaño era el principal puerto español, "llegó a sumar entre 1778 y 1796 , el $76 \%$ de todas las exportaciones españolas a América. El porcentaje del valor anual de las exportaciones de España a América en los años de 1782 - 1796 era un 400\% superior al de 1778", (Bethell, 1991, p.

\footnotetext{
${ }^{4}$ En Saint Domingue continuaron los combates entre las grandes potencias coloniales y los diferentes elementos raciales involucrados en la contienda, Toussaint Louverture, que representaba para ese entonces los intereses de Francia, había visto ensanchar el territorio francés con el Tratado de Basilea que reconocía la soberanía de Francia sobre toda la isla. Los españoles habían sido obligados a retroceder ante la fiereza del ejército colonial francés, y el mismo camino tuvo que seguir la expedición británica, la cual según Bethell, en abril 1798 sumaba la pérdida de 25,000 hombres. Superando los rigores de la guerra civil de 1799, que enfrentó al sur controlado por los mulatos contra el norte dominado por los negros, se posibilitó la formación en la parte originalmente francesa de la isla, de un gobierno centralizado en la figura de Louverture, el cual fue nombrado como gobernador general y comandante en jefe de Saint Domingue. Ver: James, C.L.R. (2001). Los jacobinos negros. México: Fondo de Cultura Económica.
} 
12). Ésta fue la época de oro del comercio gaditano, al tiempo de ser dorada también para la Gran Bretaña.

Peggy Liss señala que desde épocas tan tempranas en el calendario revolucionario como la fecha emblemática de 1789, "los ministros españoles habían reconocido que las manufacturas extranjeras eran necesarias para abastecer adecuadamente las Indias, y habían concluido que la esperanza inmediata de España consistía en funcionar como centro de intercambio comercial", (Liss, 1995, p. 236). Estas premisas obligaban a los españoles a tener muy en cuenta que una guerra prolongada contra la Gran Bretaña terminaría por destruir su flota comercial, llevando al imperio a la ruina. España conocía su realidad, se había convertido en "un simple comisionario de factorías extrajeras", (p. 235). Ese papel no era necesario y podría peligrar de no ser por la permisibilidad británica.

La nueva alianza con Francia firmada en Basilea en el verano de 1795 consagraba el reconocimiento internacional de la Francia republicana, cuestión que hacía evidente el debilitamiento de la coalición anti francesa orquestada y financiada desde la Gran Bretaña. Para Francia, la paz garantizaba el fin de una situación bélica arriesgada por la amplitud de frentes de combate y la cantidad de ejércitos enemigos golpeando las fronteras simultáneamente. El principal objetivo de la nueva alianza consistía en aislar a Gran Bretaña de sus posesiones atlánticas y frenar su expansionismo colonial, al tiempo que reemplazarla como potencia comercial en los mercados americanos a través de España. García Cárcel nos recuerda que, "la presión ejercida por Francia se sumaba especialmente al interés por frenar las acciones y amenazas británicas relacionadas con el control de las colonias y del comercio de ultramar”, (García Cárcel, 2002, p. 256).

Godoy había justificado la paz de Basilea con tres argumentos, las dificultades económicas por las que pasaba España, la carencia de tropas para hacerle frente a un avance francés más firme sobre el reino y la falta de dinero en el fisco del Estado. Es por esas razones que el Tratado de San Ildefonso era una capitulación de España ante Francia. Los británicos estaban convencidos de que a la paz seguiría una neutralidad amañada en la que España favorecería a Francia y luego una alianza que traería la guerra contra la Gran Bretaña. "España pondría a disposición de Francia un ejército de 18,000 soldados de infantería, 6,000 de caballería y una flota de 15 navíos de línea y 6 fragatas", (Lynch, 1999, p. 354). Esto era importante para Francia y le otorgaba un poder naval al que no podía aspirar por sí sola, con este comportamiento. Para España significaba una capitulación costosa e inconveniente, ya que hasta ese momento sería mucho más difícil controlar la información relacionada con la revolución y sus ideas peligrosas.

España se había vuelto un satélite de Francia, cuya única función era satisfacer las exigencias cada vez mayores y más frecuentes de su insaciable aliada. En la alianza con Francia, Godoy quería asegurarse su supervivencia política. Además del nuevo papel que jugaría España como Estado vasallo de Francia, Godoy, con 
el apoyo de Carlos IV, decidió obtener los recursos para financiar la guerra contra la Gran Bretaña modificando las relaciones tradicionales que habían venido manteniendo con la iglesia católica desde el inicio de la revolución francesa. Carlos IV obtuvo permiso del Papa para poner fin a los privilegios de exención de los diezmos de que gozaban una serie de individuos e instituciones religiosas. El gobierno de Godoy impulsó sobre el clero en torno a sus propiedades y los impuestos fueron parte de un intento por superar los obstáculos que se interponían en el camino de aumentar los ingresos y aspecto de la difícil búsqueda de ingresos en tiempos de guerra.

Ante la estrecha vigilancia marítima impuesta por los británicos, la guerra tuvo un efecto devastador, especialmente porque no había margen de maniobra. Muchas industrias peninsulares eran arcaicas, mientras el mercado interior se empobrecía progresivamente y la Francia proteccionista se mostraba abiertamente hostil a las importaciones de productos españoles. El panorama se agravaba en la medida en que desde 1796, los comerciantes españoles vieron cómo los productos procedentes del imperio iban a parar a manos de los británicos, "los ingresos de la bonanza minera se exponían al peligro de los merodeadores extranjeros, o bien cómo se reducían debido a la participación de comerciantes de otros países", (Bethell, 1991, p. 16). España perdía sus mercados americanos, las remesas del tesoro y las tasas aduaneras, lo que llevaría al fisco español a la bancarrota y a que se presentaran medidas poco ortodoxas.

Bethell contribuye a esta comprensión mostrando como España debido a la guerra contra la Gran Bretaña perdió las ganancias extraordinarias del ciclo de los precios de los metales que se registró durante esos años, "el apogeo de la gran producción de plata coincidió con la destrucción del poder naval español, y por lo tanto de su comercio colonial", (Bethell, p. 17). Los intereses de los criollos de las colonias requerían la libertad de comerciar directamente con todos los países y de exportar los productos del país sin restricciones, cuestión que se materializaría por ejemplo, en las presiones cada vez más acuciantes para mantener un constante aprovisionamiento de mercurio y equipamientos para la explotación de las minas, algo que era imposible de garantizar en medio de la guerra. Las necesidades propias de la supervivencia de América le daban a la Gran Bretaña la posibilidad de activar su comercio a través del contrabando, en lo cual era experta.

En América española, las medidas del libre comercio intraimperial impulsadas desde la época de Carlos III habían afectado la producción artesanal y la manufactura local, en beneficio de la España metropolitana hasta 1796, luego, la incapacidad metropolitana para competir con Gran Bretaña como productora de mercancías y exportadora de capitales se manifestó de forma explícita. Los puertos atlánticos y caribeños, rodeados de puestos comerciales británicos en el Caribe y el Atlántico sur o de sus aliados portugueses en los estuarios del Río de la Plata, mantuvieron en todo este periodo un intercambio constante con las flotas comerciales enemigas de la metrópoli a partir del contrabando que pululó por esos años. Wallerstein agrega que, "Precisamente allí donde la penetración extranjera fue más profunda, en Caracas y La Plata, algunos colonos empezaron a pensar 
que quizá les esperaba un futuro mejor zafándose del yugo español", (Wallerstein, p. 334).

La provincia de Venezuela, debido a su carácter caribeño y a su cercanía geográfica de las Antillas francesas, no podía estar aislada de los acontecimientos que ocurrían en Francia y en sus colonias americanas, principalmente en Saint Domingue, pues como lo presenta el historiador venezolano Ramón de Basterra en su obra Los navíos de la llustración, "no debemos olvidar que las ideas de la Ilustración y el enciclopedismo, lo mismo que la lucha de los esclavos en pro de su libertad, ya tenían su asiento en el territorio venezolano antes del estallido de la revolución francesa de 1789", (De Basterra, 1954). Las revueltas negras y pardas habían sido reprimidas exitosamente en el occidente de Venezuela pero ahora las fuerzas del péndulo gravitacional se inclinaron hacia los criollos ilustrados de Caracas, los cuales influidos por la situación internacional y por la experiencia de la conspiración republicana de Juan Picornell y otros profesores ${ }^{5}$ de la península nutría al movimiento de un sentido patriótico propio de la llustración.

La guerra de la coalición franco española contra la Gran Bretaña no hacía fácil la navegación de los mares. La batalla de San Vicente del 14 de febrero de 1797 había diezmado a la marina española, la cual en posición de debilidad tendría que continuar las hostilidades contra la Gran Bretaña. Los conspiradores peninsulares fueron enviados a cumplir prisión perpetua en las prisiones de América y fueron puestos en camino a Cartagena en la Guaira y Puerto Cabello debido a la presencia de navíos británicos en el litoral caribeño. Al poco tiempo de haber sido recluidos los presos pudieron fugarse de las fortalezas de la Guaira el día 4 de junio de $1797^{6}$, entre los que se encontraban Juan Picornell, Manuel Cortés de

\footnotetext{
${ }^{5}$ La conspiración de San Blas, cuyo grupo estaba compuesto por los nombres de Juan Bautista Picornell, Manuel Cortés de Campomanes, Sebastián Andrés y José Lax, todos hombres de letras y profesores, fue descubierta el 3 de febrero de 1796. Su objetivo principal era el de transformar la monarquía en república al estilo francés. Fueron apresados en las vísperas del estallido revolucionario e inicialmente fueron condenados a la horca y se les confiscaron sus bienes, pero la intervención del agente francés M. Perignon se les conmutó la pena de muerte por la reclusión perpetua en América. Escapando a la muerte salieron encadenados de España con destino a los puertos de América, específicamente La Guaira y Puerto Cabello a los cuales fueron confinados momentáneamente mientras se llevaba a cabo su traslado a Cartagena y Portobelo. Según las fuentes estos profesores sirvieron de promotores a la conspiración que se tejería en Caracas, conocida como de Gual y España, (nombres de sus principales líderes, Manuel Gual y José María España). Al parecer los presos y posteriormente prófugos se ponían en contacto con hombres de Tierra Firme, predicando la buena nueva, por primera vez con la chispa de la comprensión se iniciaba una acción revolucionaria criolla que fracasaría. Ver: Grases, P. (1949). La conspiración de Gual y España y el ideario de la independencia. Caracas: Instituto Panamericano de Geografía e Historia; Blanco, J. F. \& Aizpurúa, R. (1989). Documentos para la historia de la vida pública del Libertador. Caracas: Ediciones de la Presidencia de la República. P. 285.

${ }^{6}$ La fuga fue auxiliada por personal de la fortaleza de la Guaira y sus protectores facilitaron la fuga, trasladando a los prófugos primero a Curazao y desde allí a la isla de Guadalupe. El Capitán General de Caracas, Pedro Carbonell le envió a Godoy el día 28 de agosto de 1797 el comunicado donde le indicaba las averiguaciones que sobre la fuga se habían hecho hasta aquel momento. Según los testimonios de los soldados interrogados, el comandante interino de la plaza de la Guaira, Antonio López Chávez había contribuido a la fuga de los reos. Ver: Blanco, José Félix \& Aizpurúa, Ramón. Documentos para la historia de la vida pública del Libertador. Caracas, Ediciones de la Presidencia de la República, 1989, p, 310. Otras fuentes expresan que los reos fueron favorecidos por los oficiales y las tropas de milicia del puerto, que los habían mantenido ocultos en uno de los cuerpos de la guardia y luego los habían mantenido ocultos en Macuto hasta el 25 del
} 
Campomanes y Sebastián Andrés, los cuales lograron refugiarse en Macuto ${ }^{7}$ por semanas antes de encontrar el transporte que los condujo a Curazao el día 25 del mismo mes. Fue desde el exilio desde donde los prófugos pudieron irradiar sus ideas hacia Tierra Firme. Picornell y Cortés se asentaron en las Antillas francesas e imprimieron textos que con el tiempo inundaron el Caribe.

Según el autor Grases, los profesores lograron contactarse con células republicanas que orquestaron la fuga y los refugiaron hasta su partida a las Antillas. Interpretación que sería mucho más creíble que cualquier otro intento explicativo ya que al poco tiempo de la salida de los prófugos se presentó el intento de sublevación de Caracas frente al capitán general Pedro Carbonell. El día 13 de julio de 1797 fue denunciado a las autoridades los planes conspirativos de los criollos de la ciudad que tenían planeada una insurrección para enero de 1798. Buen número de los comprometidos fueron detenidos y apresados, pero los intelectuales ilustrados representados en las figuras de Manuel Gual y José María España lograron escapar hacia Curazao, allí lograron establecer contacto con el partido republicano peninsular y distribuir sus funciones de propagación de las ideas revolucionarias. Gual y España fueron a parar a la recién conquistada

mismo mes. Haciéndose evidente que aquellos reos no hubieran podido fugarse sin la ayuda de muchos. Ver: Baralt, J. M. (1939). Resumen de la historia de Venezuela desde 1797 hasta 1830. París: Descleé. P. 20.

${ }^{7}$ José Lax, que había sido recluido en Puerto Cabello no pudo ganar la libertad como sus compañeros. 
Trinidad $^{8}$, en donde las nuevas autoridades británicas los mantuvieron durante los años en que transcurrió la guerra, desde esa isla Gual mantuvo correspondencia con Francisco de Miranda, que se encontraba aun radicado en Londres.

Las Ordenanzas de la conspiración habían sido distribuidas en Caracas, Maracaibo, Cumaná y Guayana, en ellas se hacían recomendaciones de carácter práctico, cuyo objetivo era la independencia de la metrópoli ibérica, proclamando la libertad de cultivo y de comercio, al tiempo que la igualdad natural de los hombres y el fin de la esclavitud. "Aboga por armarse con lo que a mano se halle, cuchillos, machetes, picas, palos e instrumentos de cocina, citando los ejemplos de Estados Unidos y Francia". (Grases, 1949, p. 32). Al tiempo que sus consignas invitaban a las tropas patricias que debían adherirse a los negros, pardos e indios a la causa independentista. Tras la conspiración, la Real Audiencia de Caracas prohibió la obra editada por la sedición, Los derechos del hombre y del ciudadano, se decretaron penas de azote, presidio y muerte a los que divulgasen esas doctrinas y para aquellos que no frenasen su extensión ${ }^{9}$.

\section{Conclusiones}

La revolución no pudo florecer en España, en cambio en el Caribe inquieto echó sólidas y profundas raíces. A la revuelta negra de Saint Domingue sucedieron una serie de conmociones que amenazaban todo el sistema de explotación colonial esclavista. En 1793 siguió el levantamiento de los esclavos de Martinica, el año siguiente fue el turno para los de Guadalupe y en 1795 iniciaron las revueltas en Jamaica, Granada, el oriente de Cuba y el occidente de Venezuela. De esta manera, para las autoridades españolas de las colonias del Caribe, era de mayor preocupación las insurrecciones de esclavos que los conflictos internacionales contra Francia o la Gran Bretaña. Los tres millones de negros que rodeaban a Cuba desde Haití, Jamaica y la propia población esclava de la isla ayudaron a crear un clima de desconfianza que se nutría del racismo e imploraba el fomento

\footnotetext{
${ }^{8}$ Los británicos conquistaron la isla de Trinidad como consecuencia de las dificultades que había generado la batalla naval de San Vicente en el mes de febrero de 1797. Con la toma de Trinidad, posición estratégica del imperio español en el Caribe, la desconexión con América se vio seriamente perjudicada, lo que implicó una promoción del contrabando británico en los puertos americanos. Ver: García Cárcel, R. (2002). Historia de España siglo XVIII. La España de los Borbones. Madrid: Editorial Cátedra. P. 257. El prófugo criollo José María España volvió a La Guaira y fue capturado, condenado y ejecutado en Caracas el 8 de mayo de 1799. Ver: Grases, P. Ibíd, p, 30.

${ }^{9}$ El tribunal discurrió sobre las causas que habían influido en el ánimo de aquellas gentes para entrar en la trama conspirativa, asignando las siguientes: 1) La residencia en aquellas provincias de muchos hijos y descendientes de extranjeros, 2) la inconsiderada remisión a la Guaira de unos ochocientos prisioneros franceses, hechos por las tropas españolas en las operaciones militares de Saint Domingue, los cuales habrían difundido las máximas revolucionarias contagiando a la gente del país. 3) la admisión de los exiliados franceses que salieron de la isla de Trinidad cuando fue conquistada por los ingleses, 4) la inevitable introducción de papeles de las islas extranjeras y del antiguo continente a pesar de la activa vigilancia de las autoridades para prohibirlo, 5) las sugestiones del comandante inglés de la isla de Trinidad desde la cual inundaba las costas del litoral de impresos y manuscritos. Ver: Blanco, J. F. \& Aizpurúa, R. (1989). Documentos para la historia de la vida pública del Libertador. Caracas: Ediciones de la Presidencia de la República. P. 333.
} 
de la colonización blanca y la restricción a la llegada de nuevos elementos africanos.

El mensaje de la revolución halló con el tiempo un profundo eco y hasta las más apartadas regiones del mundo sometidas a crueles e implacables regímenes coloniales de explotación y esclavitud sintieron su llamado a la transformación. El imperio español en América no fue la excepción, sin embargo, los acontecimientos de Saint Domingue despertaron temores en la sociedad criolla americana hasta el punto de retrasar el camino a la emancipación hasta que fuera inevitable. A medida que la revolución francesa se volvía más radical y que cada vez se conocían mejor los acontecimientos, atraía menos a la aristocracia criolla americana. La veían como un monstruo de democracia extrema y anarquía, que si era admitida en América destruiría el mundo de privilegios del cual disfrutaban.

Saint Domingue constituyó un aviso para los criollos de la América española, pero también fue un ejemplo. Los criollos pudieron ver los resultados inevitables producidos por la falta de unidad en la metrópoli, por la pérdida de energía por parte de las autoridades y de control de la dirigencia colonial. Los hechos registrados en Saint Domingue representaban la independencia pero también la revolución, la libertad pero también la igualdad. Los criollos tendrían que enfrentarse a la crisis definitiva de su metrópoli y a la quiebra del control imperial, y el ejemplo de Saint Domingue los llevó a llenar el vacío político dejado por los españoles y a agarrase de la independencia, para evitar que sucediera lo que allí ocurrió.

A lo que hay que agregar que la revolución de Saint Domingue también generó temores ante la eventual independencia y el inicio de una guerra de castas al interior del imperio moribundo, en pugna por el poder y el establecimiento de un proyecto más democrático de república, aquel que se tomaría en serio el legado de la revolución radical que vivenciaron Francia y su territorio caribeño. A partir de las insurrecciones de José Leonardo Chirino en Coro y de Nicolás Morales en Bayamo, la represión, control y vigilancia en las provincias coloniales de la capitanías generales de Venezuela y Cuba se fue organizando y perfeccionando gradualmente, ante el temor de una verdadera influencia francesa y haitiana a través de papeles y libros sediciosos, como se evidenció más tarde en la publicación de los derechos del hombre y del ciudadano por la Conspiración de Gual y España en 1797.

\section{Fuentes Documentales}

A.G.N. (Archivo General de la Nación, Bogotá, Colombia)

A.N.H. (Archivo Nacional de La Habana, Cuba)

Lacroix, P. (1820). Mémoires pour servir a L'Histoire de la révolution du Saint Domingue. Paris. 
Von Humbolt, A. (1956). Viaje a las regiones equinocciales del Nuevo Continente. Caracas.

\section{Bibliografía}

Aizpurua, R. (1988). La insurrección de los negros de la serranía de Coro en 1795: Una revisión necesaria". En Boletín de la Academia Nacional de Historia, Tomo LXXI, N² 233 (julio - septiembre). Caracas

Arcaya, P. M. (1979). La insurrección de los negros de la serranía de Coro: 10 de mayo de 1795. Caracas: Academia Nacional de Historia.

Aymes, J. R. (1989). España y la revolución francesa. Barcelona: Editorial Crítica.

Baralt, J. M. (1939). Resumen de la historia de Venezuela desde 1797 hasta 1830. París: Descleé.

Bethell, L. (Comp.) (1991). Historia de América Latina. Vol 5 Barcelona: Crítica.

Blanco, J. F. \& Aizpurúa, R. (1989). Documentos para la historia de la vida pública del Libertador. Caracas: Ediciones de la Presidencia de la República.

Britto Figueroa, F. (1993). Historia económica y social de Venezuela. Una estructura para su estudio. Caracas: U.C.V.

Britto Figueroa, F. (1996). El problema de la tierra y los esclavos en la historia de Venezuela. Caracas: Universidad Central de Venezuela.

Callahan, W. (1967). "La propaganda, la sedición y la revolución francesa en la Capitanía General de Venezuela, 1789 - 1796”. En Boletín Histórico. , No 14, (mayo). Caracas.

Carr, R. (2001). Historia de España. Barcelona: Península.

Césaire, A. (1967). Toussaint Louverture. La revolución francesa y el problema colonial. La Habana: Instituto del Libro.

De Basterra, R. (1954). Una empresa del siglo XVIII. Los navíos de la llustración. Caracas: Ediciones de la Presidencia de la República.

Dubois, L. (2004). Avengers of the New World. The History of the Haitian Revolution. Cambridge: Harvard University Press.

Edsel, C. et all. (1996). José Leonardo Chirino y la insurrección de la serranía de Coro de 1795, insurrección de libertad o rebelión de independencia. Mérida: Universidad de los Andes. 
Franco, J. L. (1965). Revoluciones y conflictos internacionales en el Caribe, 1789 1854. La Habana: Academia de Ciencias.

Franco, J. L. (1989a). Ensayos sobre el Caribe. La Habana: Editorial de Ciencias Sociales.

García Cárcel, R. (Comp.) (2002). Historia de España siglo XVIII. La España de los Borbones. Madrid: Editorial Cátedra.

Fortoul, J. (1964). Historia Constitucional de Venezuela. Caracas: Ediciones Sales.

González Ripoll, M. et all. (2004). El rumor de Haití en Cuba: temor, raza y rebeldía, 1789 - 1844. Madrid: Consejo Superior de Investigaciones Científicas.

Grases, P. (1949). La conspiración de Gual y España y el ideario de la independencia. Caracas: Instituto Panamericano de Geografía e Historia.

Guerra Vilaboy, S. (2007). El dilema de la independencia. La Habana: Editorial Ciencias Sociales.

Harvey, R. (2000). Los Libertadores. La lucha por la independencia de América Latina, 1810 - 1830. Barcelona: RBA Libros.

Havard, G. \& Vidal, C. (2005). Histoire de L'Amérique Francaise. París: Flammarion.

James, C.L.R. (2001). Los jacobinos negros. México: Fondo de Cultura Económica.

Liss, P. K. (1995). Los imperios trasatlánticos. Las redes del comercio y las Revoluciones de Independencia. México: Fondo de Cultura Económica.

Lynch, J. (2001). América Latina, entre colonia y nación. Barcelona: Crítica.

Solé, J. (2006). Las revoluciones de fin del siglo XVIII en América y Europa, 1773 - 1804. Madrid: Siglo XXI Editores.

Wallerstein, I. (2006). El moderno sistema mundial. La segunda era de gran expansión de la economía mundo capitalista, 1730 - 1850. Tomo III. México: Siglo XXI Editores.

Fecha de recepción: 23 de abril de 2009

Fecha de aprobación: 21 de septiembre de 2009 